\title{
Acetone-CO enhancement ratios in the upper troposphere based on 7 years of CARIBIC data: new insights and estimates of regional acetone fluxes
}

\author{
Garlich Fischbeck $^{1}$, Harald Bönisch ${ }^{1}$, Marco Neumaier ${ }^{1}$, Carl A. M. Brenninkmeijer ${ }^{2}$, Johannes Orphal $^{1}$, Joel Brito ${ }^{3}$, \\ Julia Becker ${ }^{1}$, Detlev Sprung ${ }^{4}$, Peter F. J. van Velthoven ${ }^{5}$, and Andreas Zahn ${ }^{1}$ \\ ${ }^{1}$ Karlsruhe Institute of Technology (KIT), Institute of Meteorology and Climate Research (IMK-ASF), Karlsruhe, Germany \\ ${ }^{2}$ Max Planck Institute for Chemistry (MPIC), Air Chemistry Division, Mainz, Germany \\ ${ }^{3}$ Laboratory for Meteorological Physics (LaMP), University Blaise Pascal, Aubière, France \\ ${ }^{4}$ Fraunhofer Institute of Optronics, System Technologies and Image Exploitation (IOSB), Ettlingen, Germany \\ ${ }^{5}$ Royal Netherlands Meteorological Institute (KNMI), De Bilt, the Netherlands
}

Correspondence to: Marco Neumaier (marco.neumaier@kit.edu)

Received: 6 September 2016 - Discussion started: 15 September 2016

Revised: 22 December 2016 - Accepted: 29 December 2016 - Published: 9 February 2017

\begin{abstract}
Acetone and carbon monoxide (CO) are two important trace gases controlling the oxidation capacity of the troposphere; enhancement ratios (EnRs) are useful in assessing their sources and fate between emission and sampling, especially in pollution plumes. In this study, we focus on in situ data from the upper troposphere recorded by the passenger-aircraft-based IAGOS-CARIBIC (In-service Aircraft for a Global Observing System-Civil Aircraft for the Regular Investigation of the atmosphere Based on an Instrument Container) observatory over the periods 2006-2008 and 2012-2015. This dataset is used to investigate the seasonal and spatial variation of acetone-CO EnRs. Furthermore, we utilize a box model accounting for dilution, chemical degradation and secondary production of acetone from precursors. In former studies, increasing acetone-CO EnRs in a plume were associated with secondary production of acetone. Results of our box model question this common presumption and show increases of acetone-CO EnR over time without taking secondary production of acetone into account. The temporal evolution of EnRs in the upper troposphere, especially in summer, is not negligible and impedes the interpretation of EnRs as a means for partitioning of acetone and $\mathrm{CO}$ sources in the boundary layer. In order to ensure that CARIBIC EnRs represent signatures of source regions with only small influences by dilution and chemistry, we limit our analysis to temporal and spatial coherent
\end{abstract}

events of high-CO enhancement. We mainly focus on North America and Southeast Asia because of their different mix of pollutant sources and the good data coverage. For both regions, we find the expected seasonal variation in acetoneCO EnRs with maxima in summer, but with higher amplitude over North America. We derive mean ( \pm standard deviation) annual acetone fluxes of $(53 \pm 27) 10^{-13} \mathrm{~kg} \mathrm{~m}^{-2} \mathrm{~s}^{-1}$ and $(185 \pm 80) 10^{-13} \mathrm{~kg} \mathrm{~m}^{-2} \mathrm{~s}^{-1}$ for North America and Southeast Asia, respectively. The derived flux for North America is consistent with the inventories, whereas Southeast Asia acetone emissions appear to be underestimated by the inventories.

\section{Introduction}

Acetone $\left(\mathrm{CH}_{3} \mathrm{COCH}_{3}\right)$ is the most abundant small ketone in the upper troposphere (UT) with mixing ratios occasionally exceeding $2 \mathrm{ppb}$ in summer (Singh et al., 1994; Pöschl et al., 2001; own measurements). In the dry UT, acetone constitutes an important source of $\mathrm{HO}_{x}$ radicals and ozone (e.g. Singh et al., 1995; McKeen et al., 1997; Folkins and Chatfield, 2000; Neumaier et al., 2014). At high-NO $\mathrm{NO}_{x}$ levels, acetone can form peroxyacetyl nitrate (PAN), which acts as a temporary reservoir for $\mathrm{NO}_{x}$ thus enabling long-range transport of reactive nitrogen (Singh et al., 1986, 1992; Folkins 
and Chatfield, 2000; Hansel and Wisthaler, 2000; Fischer et al., 2014). Consequently, acetone is considered to be a key species in the chemistry of the upper troposphere and lower stratosphere (UTLS) (e.g. Fischer et al., 2012; Neumaier et al., 2014).

Acetone is either directly emitted by anthropogenic and biogenic sources or formed in the atmosphere by oxidation of precursor compounds (e.g. $>\mathrm{C}_{2}$ alkanes). Biogenic sources (including secondary production from biogenic precursors) are believed to account for $\sim 50-70 \%$ of the total acetone emissions (Jacob et al., 2002; Fischer et al., 2012; Hu et al., 2013; Khan et al., 2015). Until recently, propane was thought to be the dominant acetone precursor accounting for $\sim 30 \%$ of the total acetone budget (Fischer et al., 2012). However, the latest STOCHEM-CRI model calculations by Khan et al. (2015) suggest that oxidation of short-lived biogenic compounds such as $\alpha$-pinene and $\beta$-pinene could account for more than $60 \%$ of atmospheric acetone with propane oxidation being much less important $(\sim 12 \%)$. The contribution from $\mathrm{C}_{4}$ to $\mathrm{C}_{5}$ alkanes is expected to be 6-7\% (Jacob et al., 2002; Fischer et al., 2012).

Acetone is also directly emitted from biomass burning (BB) (Holzinger et al., 1999; Holzinger et al., 2005) with an estimated contribution of $\sim 4-10 \%$ to the global source (Jacob et al., 2002; Singh et al., 2004; Fischer et al., 2012). The main tropospheric sinks of acetone are oxidation by $\mathrm{OH}$ and photolysis, with about equal importance in the midlatitudes. The resulting overall tropospheric mean lifetime of acetone is in the range of 14-35 days (Jacob et al., 2002; Schade and Goldstein, 2006; Fischer et al., 2012; Hu et al., 2013; Khan et al., 2015). Despite an increasing number of UT measurements of acetone (mainly from several research aircraft campaigns), it is obvious that there continues to be a paucity of representative data of global atmospheric acetone. To tackle this problem, efforts have been made to retrieve acetone from ACE-FTS (Coheur et al., 2007; Harrison et al., 2011; Tereszchuk et al., 2013; Dufour et al., 2016) and MIPAS (Moore et al., 2012) satellite data, but the signature of acetone is hard to detect (Stiller et al., 2004; Waterfall et al., 2004) and the vertical resolution of the respective instruments is limited to 2-3 km (Moore et al., 2012; Dufour et al., 2016). Therefore, limited acetone data have been provided this way. Given the poor understanding of the oceans as an acetone reservoir (Marandino et al., 2005; Fischer et al., 2012; Dixon et al., 2013) and the strong temporal and spatial variability of other sources, constraining the global acetone source clearly requires more extended datasets. Current global source estimates range from $42.5 \mathrm{Tg} \mathrm{a}^{-1}$ (Arnold et al., 2005) to $127 \mathrm{Tg} \mathrm{a}^{-1}$ (Elias et al., 2011).

In this study, we adopt the approach of Zahn et al. (2002), who identified correlations between carbon monoxide (CO) and ozone $\left(\mathrm{O}_{3}\right)$ from small to regional scales in the CARIBIC (Civil Aircraft for the Regular Investigation of the atmosphere Based on an Instrument Container) dataset, and investigate the relationship of acetone and $\mathrm{CO}$ using 7 years of
IAGOS (In-service Aircraft for a Global Observing System)CARIBIC measurements covering large parts of the Northern Hemisphere.

The paper is organized as follows. In Sect. 2, we introduce the concept of enhancement ratios (EnRs). The IAGOSCARIBIC project and the applied measurement techniques are described in the Sect. 3.1 to 3.3. In Sect. 3.4, we explain how to analyse the data. The emission inventories used for comparison with CARIBIC EnRs are described in Sect. 3.5. In Sect. 4.1, we use a box model to examine the temporal evolution of EnR. The results derived from the statistical analysis of the full dataset are presented in Sect. 4.2 and 4.3. We summarize the results and give a conclusion in Sect. 5 .

\section{The concept of enhancement ratios}

A powerful tool for quantifying acetone emissions is the analysis of EnRs in plumes (e.g. Singh et al., 2004; Lai et al., 2011). The EnR is obtained by dividing the plume enhancement of a species $X$ (above to the background) by the enhancement of another species $Y$ (Lefer et al., 1994; Lee et al., 1997; Mauzerall et al., 1998):

$\operatorname{EnR}=\frac{[X]_{\text {plume }}-[X]_{\text {bgnd }}}{[Y]_{\text {plume }}-[Y]_{\text {bgnd }}}$.

For acetone, it became common practice to use $\mathrm{CO}$ as a reference species, because both gases are emitted during incomplete combustion (Andreae and Merlet, 2001; Wisthaler et al., 2002; Greenberg et al., 2006; Warneke et al., 2011). In practice, the EnR is either determined by measuring the volume mixing ratios (VMRs) inside and outside the plume (e.g. Simpson et al., 2011) or from continuous airborne measurements during plume passage (see Fig. 1) (Yokelson et al., 2013). In a scatter plot, the data points will ideally lie on the mixing line that connects the higher concentrations in the plume with the background.

When an EnR is measured at the source, it equals its molar emission ratio (ER) (Yokelson et al., 2013). Downwind from the source, the EnR remains equal to the ER as long as production or removal of $X$ and $Y$ in the plume are negligible and as long as the plume mixes in the same fixed background (Mauzerall et al., 1998; Yokelson et al., 2013). This is due to the fact that dividing the enhancement of $X$ by the enhancement of $Y$ normalizes for dilution, as both species dilute at the same rate (Akagi et al., 2012; Yokelson et al., 2013). We prefer to use EnR whenever it cannot be excluded that the ratio has changed since emission. As shown in Fig. 1, this is particularly the case for measurements in the UT. Plume air initially mixes with planetary boundary layer (PBL) air and subsequently enters the "cleaner" UT. Plume ratios observed in the UT significantly differ from the PBL EnR value simply because the UT background has a different acetone- $\mathrm{CO}$ ratio as the PBL background. 
Table 1. Literature values of acetone-CO emission ratios (ERs) in $\mathrm{ppt}_{\mathrm{ppb}}{ }^{-1}$.

\begin{tabular}{lll}
\hline ER & Air mass, location, time & References \\
\hline $0.06-0.25$ & Biofuel burning & Andreae and Merlet (2001) \\
0.84 & Vegetation from the southwest USA; laboratory experiment & Warneke et al. (2011) \\
1.2 & Savanna biomass burning & Akagi et al. (2011) \\
1.6 & Fresh Canadian boreal biomass burning plumes, June-July 2008 & Simpson et al. (2011) \\
$1.7-2.05$ & North American wildfires & Friedli et al. (2001) \\
$1.9-4.6$ & Savanna and grassland biomass burning & Andreae and Merlet (2001) \\
$2.3-2.7$ & Extratropical forest biomass burning & Andreae and Merlet (2001) \\
1.93 & Vegetation from the southeast USA; laboratory experiment & Warneke et al. (2011) \\
1.94 & Pines spruce; laboratory experiment & Warneke et al. (2011) \\
2.8 & Boreal forest biomass burning & Akagi et al. (2011) \\
2.9 & Peatland burning & Akagi et al. (2011) \\
2.9 & Tropical forest biomass burning & Andreae and Merlet (2001) \\
2.9 & Charcoal burning & Andreae and Merlet (2001) \\
2.9 & Residential heating & Kaltsonoudis et al. (2016) \\
3.0 & Extratropical/boreal forest biomass burning & Akagi et al. (2011) \\
3.3 & Tropical forest biomass burning & Akagi et al. (2011) \\
4.8 & Fresh savannah fire, Africa & Jost et al. (2003) \\
5.4 & Savanna grass, laboratory experiment & Holzinger et al. (1999) \\
\hline $2.5 \pm 1.3$ & Mean acetone-CO ER & \\
\hline
\end{tabular}

Table 2. Literature values of acetone-CO enhancement ratios (EnRs) in biomass burning plumes in ppt ppb ${ }^{-1}$.

\begin{tabular}{lll}
\hline EnR & Air mass, location, time & References \\
\hline 4.7 & Fresh biomass burning plume, summer 2008 & Singh et al. (2010) \\
5.0 & Biomass burning plumes, Canada, June-July 2008 & Hornbrook et al. (2011) \\
5.7 & Aged boreal biomass burning plumes from North America, July-August 2011 & Tereszchuk et al. (2013) \\
6.0 & Biomass burning plumes, California, June-July 2008 & Hornbrook et al. (2011) \\
6.2 & Aged boreal biomass burning plumes from Siberia, July-August 2011 & Tereszchuk et al. (2013) \\
6.3 & Aged plumes of Alaskan and Canadian forest fire, July 2004 & de Gouw et al. (2006); \\
6.6 & Aged Biomass burning plumes, Yucatan, March 2006 & Yokelson et al. (2009) \\
$6.6-22$ & Aged biomass burning plumes, free troposphere, Pacific, winter/spring 2001 & Jost et al. (2002) \\
$7.2-10.3$ & Biomass burning plumes, South Atlantic, September-October 1992 & Mauzerall et al. (1998) \\
7.1 & Biomass burning plumes, Canada, June-July 2008 & Hornbrook et al. (2011) \\
7.5 & Biomass burning plumes, Pacific, winter/spring 2001 & Singh et al. (2004) \\
7.7 & Forest Fire Lake Baikal, April 2008 & de Gouw et al. (2009) \\
9.0 & Asian biomass burning plumes, June-July 2008 & Hornbrook et al. (2011) \\
10.6 & Aged (1-5 days) biomass burning and urban plumes, summer 2008 & Singh et al. (2010) \\
11.3 & Fresh savannah fire plumes (0-125 min plume age), Africa & Jost et al. (2003) \\
11.7 & Agricultural fires Kazakhstan, April 2008 & de Gouw et al. (2009) \\
14.3 & Fresh boreal biomass burning plumes from Siberia, July-August 2011 & Tereszchuk et al. (2013) \\
16.8 & Fresh boreal biomass burning plumes from North America, July-August 2011 & Tereszchuk et al. (2013) \\
18 & Aged biomass burning plumes, Crete, August 2001 & Holzinger et al. (2005) \\
20.4 & Young biomass burning plume, Tanzania, October 2005 (using background VMR over Pacific Ocean) & Coheur et al. (2007) \\
\hline $9.9 \pm 4.6$ & Mean acetone-CO EnR &
\end{tabular}

The most comprehensive overview of acetone-CO EnRs to date has been given by de Reus et al. (2003), using data of five research aircraft campaigns. For each campaign, the authors split the data into measurements from the marine boundary layer $(0-1 \mathrm{~km})$, free troposphere $(1-12.5 \mathrm{~km})$ or lower stratosphere $\left(\mathrm{O}_{3}>150 \mathrm{ppb}, \mathrm{CO}<60 \mathrm{ppb}\right)$ and derived one EnR per layer. Please note, that in this way, data of dif- ferent flights, i.e. data of "unrelated" measurements in terms of distance and time span, were used to derive a single EnR estimate. The authors found different EnRs for the different layers, but, surprisingly, consistent values among the campaigns. Since then, EnRs have been frequently reported for individual plumes and various conditions. In Tables $1-3$, we give an overview of literature acetone-CO ERs and EnRs, 
Table 3. Literature values of acetone-CO enhancement ratios (EnRs) in air masses unaffected by biomass burning in ppt ppb ${ }^{-1}$.

\begin{tabular}{lll}
\hline EnR & Air mass, location, time & References \\
\hline 1.57 & Urban air, central eastern China, March-April 2011 & Yuan et al. (2013) \\
3.18 & Urban air, London, winter 2012 & Valach et al. (2014) \\
3.4 & Free troposphere, Indian Ocean, February-March 1999 & Reiner et al. (2001) \\
3.59 & Urban air (with vehicular emissions), Sao Paolo, February-April 2013, & Brito et al. (2015) \\
5.0 & Mount Tai, China, June 2006 & Inomata et al. (2010) \\
5.8 & Fresh urban plumes, eastern USA, July-August 2004 & Warneke et al. (2007) \\
6.12 & High-altitude (> 9km), Pacific Ocean, February-March 1994 & McKeen et al. (1997) \\
$13-16$ & Marine boundary layer & De Reus et al. (2003) \\
$13.4-17.2$ & Ship measurements, Indian Ocean, March 1999 & Whistaler et al. (2002) \\
14 & Marine boundary layer, Indian Ocean, March 1999 & Reiner et al. (2001); \\
14.2 & Los Angeles, April-May 2002 & Warneke et al. (2007) \\
18.3 & Urban plumes, summer 2008 & Singh et al. (2010) \\
19.5 & Aged high-altitude plumes, Surinam, March 1998 & Andreae et al. (2001) \\
$21-25$ & Free troposphere & De Reus et al. (2003) \\
$\sim 22$ & Los Angeles Basin, May-June 2010 & Warneke et al. (2012) \\
30 & Troposphere, eastern Canada, July-August 1990 & Singh et al. (1994) \\
\hline $12.5 \pm 8.6$ & Mean acetone-CO EnR & \\
\hline
\end{tabular}

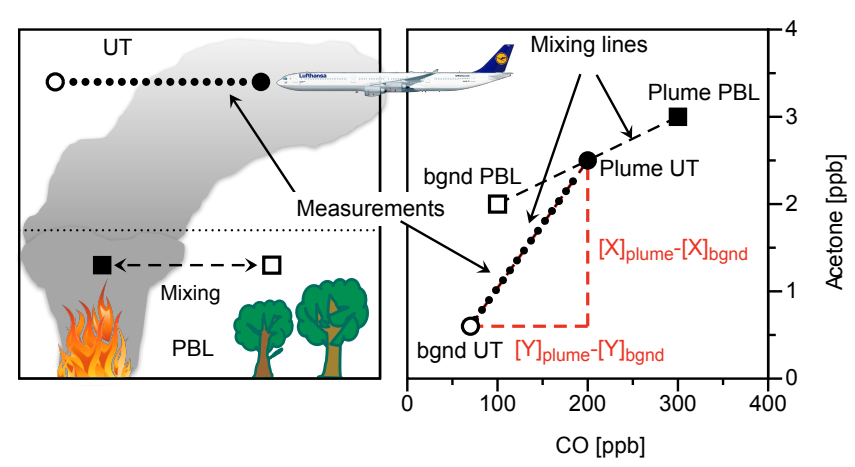

Figure 1. Left: schematic drawing (adapted from Mauzerall et al., 1998) of a biomass burning plume and its transport from the planetary boundary layer (PBL) into the upper troposphere (UT), where sampling takes place. Right: acetone plotted versus $\mathrm{CO}$ concentrations. Black-filled square (plume PBL): acetone-CO concentration in the fresh plume near the ground, which initially mixes with adjacent background (bgnd) air of the PBL (open square, bgnd PBL). When the resulting plume (full circle) rises into the upper troposphere, the enhancement of acetone and $\mathrm{CO}$ are reduced as the plume mixes with background air of the UT (open circle, bgnd UT). In an ideal case, measured concentrations lie on the UT mixing line when the aircraft passes the plume. The slope of the mixing lines, equivalent to EnR (see Eq. 1), may differ considerably in the PBL and the UT.

without any claim to completeness. It is worth noting that ERs are only available for biomass and biofuel burning and are generally lower (mean: $2.5 \mathrm{ppt} \mathrm{ppb}^{-1}$ ) than the observed free-tropospheric EnRs, which are on average $9.9 \mathrm{ppt} \mathrm{ppb}^{-1}$ for biomass burning plumes and $12.5 \mathrm{ppt} \mathrm{ppb}^{-1}$ for other plumes. In order to understand the underlying processes that change the EnR, it is worth estimating how fast plumes usually mix with background air masses. In simple models, this mixing is prescribed with a constant dilution rate. In a few studies, dilution rates were determined experimentally; the results are summarized in Table 4.

\section{Methods}

\subsection{IAGOS-CARIBIC project}

In the CARIBIC project, regular atmospheric measurements are conducted on board a commercial passenger aircraft (Brenninkmeijer et al., 2007). The present aircraft is a Lufthansa Airbus A340-600 equipped with a multi-line air inlet system (installed below the forward cargo bay) to supply the instruments with sample air. Currently, 15 instruments for in situ and 1 for remote sensing measurements of trace gases and aerosols as well as sample collecting systems for trace gas and aerosol are installed in a modified airfreight container (1.6t). Since May 2005, the CARIBIC laboratory has been monthly deployed during regular service for 4-6 consecutive long-range flights. Detailed meteorological analysis for the CARIBIC flights (including backward and forward trajectories) is based on ECMWF (European Centre for Medium-Range Weather Forecasts) model data and provided by van Velthoven (2016). In 2008, CARIBIC joined the European Research Infrastructure IAGOS and has been referred to as IAGOS-CARIBIC since then (Petzold et al., 2015). In April 2015, the coordination and operation of CARIBIC was handed over from the Max Planck Institute for Chemistry (MPIC) to the Karlsruhe Institute of Technology (KIT). Further information about the project, flight routes and data 
Table 4. Dilution rates in the literature.

\begin{tabular}{lll}
\hline Dilution rate $\left(\right.$ day $\left.^{-1}\right)$ & Location, time & References \\
\hline 0.1 & Atlantic air masses, summer & Arnold et al. (2007) \\
0.1 & Inside smoke plume, July & Pisso et al. (2009) \\
$0.16(0.05-0.2)$ & Biomass burning plume over North Atlantic, summer & Real et al. (2007) \\
0.24 & Free troposphere, April & Price et al. (2004) \\
1 & Outside smoke plume, July & Pisso et al. (2009) \\
1.44 & Planetary boundary layer, South Africa, winter & Igbafe et al. (2006) \\
1.5 & Mexico City plateau, March & Voss et al. (2010); Shrivastava et al. (2011) \\
5.5 & Planetary boundary layer, California, summer & Dillon et al. (2002) \\
$4.8-10.3$ & Planetary boundary layer, Germany & Kramp and Volz-Thomas (1997) \\
\hline
\end{tabular}

access can be obtained from the regularly updated project website (http://www.caribic-atmospheric.com).

\subsection{Acetone measurements}

In IAGOS-CARIBIC, we use a proton transfer reaction mass spectrometer (PTR-MS) for the detection of acetone and other volatile organic compounds (VOCs), e.g. acetonitrile (Sprung and Zahn, 2010). Here, we briefly describe the PTRMS and refer to the extensive literature for details (e.g. Lindinger et al., 1998; de Gouw and Warneke, 2007). In general, a PTR-MS consists of an ion source, a reaction chamber, a mass analyser and a detection unit. In the ion source, $\mathrm{H}_{3} \mathrm{O}^{+}$ ions are produced and injected into a drift tube (= reaction chamber), which is continuously flushed with sample air and where $\mathrm{H}_{3} \mathrm{O}^{+}$ions react with VOCs in the sample via the following reaction:

$\mathrm{VOC}+\mathrm{H}_{3} \mathrm{O}^{+} \stackrel{k_{\mathrm{VOC}}}{\longrightarrow} \mathrm{VOC}-\mathrm{H}^{+}+\mathrm{H}_{2} \mathrm{O}$.

The reaction takes place with the compound-related collision rate $k_{\mathrm{VOC}}$ if the proton affinity (PA) of the VOC (for acetone $\mathrm{PA}_{\mathrm{Ac}}=812 \mathrm{~kJ} \mathrm{~mol}^{-1}$ ) is higher than $\mathrm{PA}_{\mathrm{H}_{2} \mathrm{O}}\left(\approx 697 \mathrm{~kJ} \mathrm{~mol}^{-1}\right)$. The protonated VOCs and the remaining primary ions are guided by an electrical field towards the end of the drift tube and further to a quadrupole mass analyser. Protonated acetone is detected at the massto-charge ratio $m / z$ 59. Since isobaric compounds are not separated with this technique, an unambiguous assignment to specific compounds is not always possible. In principle, the signal at $\mathrm{m} / \mathrm{z} 59$ may also have contributions from protonated propanal and glyoxal. However, other studies have shown that the contribution of propanal and glyoxal are negligible compared to acetone in free-tropospheric measurements (Warneke et al., 2003; de Gouw and Warneke, 2007).

The ratio of the $\mathrm{VOC}-\mathrm{H}^{+}$and $\mathrm{H}_{3} \mathrm{O}^{+}$count rates (given in cps $=$ counts per second) is proportional to the VMR of the respective VOC in the sample air. As the $\mathrm{H}_{3} \mathrm{O}^{+}$count rate varies over longer time periods, the proportional factor and the count rates are normalized to $10^{6}$ primary ion counts $(\mathrm{ncps}=$ normalized counts per second). The proportional factor, known as sensitivity, is regularly derived in the laboratory by sampling a calibration gas with certified VOC concentrations (Apel-Riemer Environmental, Inc., Colorado, USA) under similar experimental conditions as during flight. The precision of the acetone measurement is mainly determined by counting statistics (de Gouw et al., 2003) and can be expressed as

$\Delta[\mathrm{Acc}]_{\mathrm{ppb}}=\frac{1}{S_{\mathrm{Ac}} \cdot\left[\mathrm{H}_{3} \mathrm{O}^{+}\right]_{10^{6} \mathrm{cps}}} \sqrt{\frac{[\mathrm{Ac}]_{\mathrm{cps}}^{\mathrm{sample}}+[\mathrm{Ac}]_{\mathrm{cps}}^{\mathrm{bgnd}}}{t_{\mathrm{dwell}}}}$,

where $S_{\mathrm{Ac}}$ is the sensitivity of acetone, $t_{\mathrm{dwell}}$ the dwell time of the measurement at $m / z=59$ and [Ac] ${ }^{\text {bgnd }}$ the count rate measured at $m / z=59$ in the absence of acetone. With a mean observed sensitivity of $30 \mathrm{ncps} \mathrm{ppb}^{-1}$, a mean primary ion signal of $6 \times 10^{6} \mathrm{cps}$, a dwell time of $5 \mathrm{~s}$ and a mean background signal of $60 \mathrm{cps}$, the precision is $\sim 3-5 \%$ at typical acetone VMRs of $0.5-2$ ppb. Since 2010 the noise has been on average $\sim 2$ times higher than noise derived from counting statistics in Eq. (3) due to imperfect electrical grounding.

The chemical background determines the limit of detection, which corresponds to a signal-to-noise ratio of 3 and is $\sim 140 \mathrm{ppt}$ for acetone at $5 \mathrm{~s}$ integration time. The accuracy is limited largely by the uncertainty of the concentration in the calibration gas, which is given as $\pm 5 \%$ by the manufacturer. The CARIBIC PTR-MS runs in the multiple ion detection mode and scans 16 masses within a duty cycle of $30 \mathrm{~s}$, corresponding to $7.5 \mathrm{~km}$ flight distance at cruising speed. Background measurements are conducted every $50 \mathrm{~min}$ by diverting the sample flow for 5 min through a catalytic converter filled with a Pt catalyst (Shimadzu Corp., Japan) kept at $350{ }^{\circ} \mathrm{C}$.

\subsection{Carbon monoxide and ozone measurements}

Carbon monoxide (CO) is measured with a vacuum ultraviolet (UV) resonance fluorescence instrument (Scharffe et al., 2012) with a time resolution of $1 \mathrm{~Hz}$. The $\mathrm{CO}$ molecule absorbs photons from a UV lamp (143-155 nm) and emits fluorescence light over the spectral range of $150-220 \mathrm{~nm}$. The number of fluorescence photons, being proportional to the $\mathrm{CO}$ concentration, is detected with a photomultiplier. The 
precision of the instrument is $1-2 \mathrm{ppb}$ at an integration time of $1 \mathrm{~s}$ (Scharffe et al., 2012). Ozone $\left(\mathrm{O}_{3}\right)$ is measured with a fast and precise chemiluminescence detector described in Zahn et al. (2012) and calibrated using a likewise installed $\mathrm{UV}$ photometer. At typical $\mathrm{O}_{3}$ mixing ratios $(10-100 \mathrm{ppb})$, the precision is $0.3-1.0 \%$ at $10 \mathrm{~Hz}$.

\subsection{Data analysis}

Data from the individual IAGOS-CARIBIC instruments are combined into single "merge" files for each flight with a time binning of $10 \mathrm{~s}$. Data with a sampling frequency $>0.1 \mathrm{~Hz}$, such as the $\mathrm{CO}$ measurements $(1 \mathrm{~Hz})$, are averaged over the $10 \mathrm{~s}$ intervals, whereas low-frequency data $(<0.1 \mathrm{~Hz})$, like the acetone measurements $(0.03 \mathrm{~Hz})$, are assigned to the corresponding $10 \mathrm{~s}$ interval. The correlation analysis is restricted to UT air masses. Data from ascend and descend are rarely available because of the long run-up time of the PTR-MS after take-off and an automatic equipment shutdown procedure well before landing. Stratospheric acetone-CO correlations are not well suited for our purpose to investigate source patterns, because of the long transport times. To exclude stratospheric data, we use our concomitant CARIBIC ozone data and apply the definition of the chemical tropopause as proposed by Zahn and Brenninkmeijer (2003) and Zahn et al. (2004) and verified by Thouret et al. (2006). Air masses with an ozone concentration above the threshold value of

$\left[\mathrm{O}_{3}\right]_{\mathrm{ppb}}^{\mathrm{TP}}=97+26 \sin \left(2 \pi \frac{\mathrm{doy}-30}{365}\right)$,

where doy denotes day of the year, are identified as stratospheric and excluded. In the rare event of ozone data being unavailable, we use potential vorticity (PV) calculated from the ECMWF model and discard measurements with a PV $>2$ pvu, a threshold commonly used to define the dynamical tropopause (e.g. Hoskins et al., 1985; Holton et al., 1995). In this way, $42 \%$ of the acetone-CO data were identified as stratospheric.

In the remaining dataset, we search for physically meaningful correlations in all possible subsets of data fulfilling the following two requirements adapted from Zahn et al. (2002) and Brito, 2012: (i) The subset consists of at least 10 successive measurements that are no further apart from each other than $50 \mathrm{~km}$ and cover less than $500 \mathrm{~km}$ flight path; (ii) The range of $\mathrm{CO}$ VMRs in the subset is greater than 10 times the average measurement uncertainty of $\mathrm{CO}$. These criteria ensure that only temporal and spatial coherent events with a "fresh" source signature are considered and will be discussed in more detail in Sect. 4.1. For each possible subset, Pearson's linear correlation coefficient $r$ and corresponding $p$ value are calculated. We assume a good linear correlation in the event $r>0.5$ and $p<0.05$ (5\% significance level). In such a case, the slope is calculated using the bivariate least-squares method of Williamson-York (York, 1966; Williamson, 1968; York et al., 2004) as suggested by

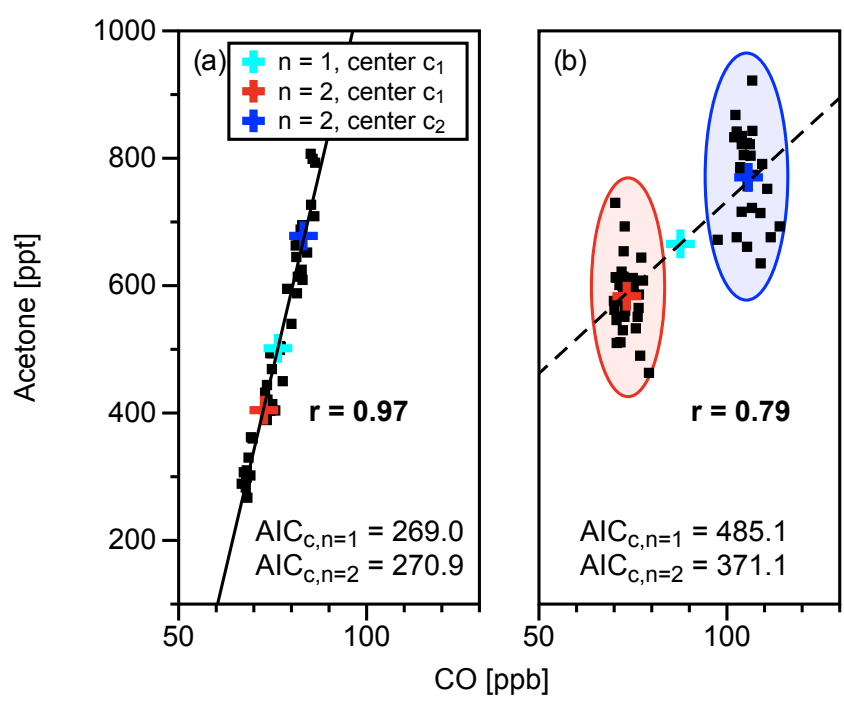

Figure 2. Scatter plots of two exemplary subsets of subsequently measured acetone and CO VMRs. (a) Shows a subset with highly correlated data $(r=0.97)$ and no visible clustering, which is also confirmed by the cluster analysis $\left(\mathrm{AIC}_{\mathrm{C}, n=1} \leq \mathrm{AIC}_{\mathrm{C}, n=2}\right)$. (b) Two distinct clusters are visible and automatically identified by the cluster analysis $\left(\mathrm{AIC}_{\mathrm{C}, n=1}>\mathrm{AIC}_{\mathrm{C}, n=2}\right)$. Although the Pearson's correlation coefficient indicates a good correlation $(r=0.79)$, this subset is rejected for determination of EnR.

Cantrell (2008). The Williamson-York fit has the advantage in that it accounts for the different uncertainties of both acetone and $\mathrm{CO}$ measurements and precludes a dependence of EnR on the axis assignments.

A high Pearson's correlation coefficient can also arise when respective acetone-CO VMRs form two clusters. To exclude such physically meaningless correlations, we implemented a cluster analysis based on Gaussian mixture models (GMMs) (Everitt and Hand, 1981; McLachlan and Peel, 2000). In our case, two GMMs are fitted to the acetone-CO subset. The first model expects only one cluster and the second two clusters. In order to choose the best-fitting model, we use the corrected Akaike's information criterion $\left(\mathrm{AIC}_{\mathrm{C}}\right)$ (Sugiura, 1978; Hurvich and Tsai, 1989). Subsets with an $\mathrm{AIC}_{\mathrm{C}}$ suggesting two clusters $\left(\mathrm{AIC}_{\mathrm{C}, n=2}<\mathrm{AIC}_{\mathrm{C}, n=1}\right)$ are discarded. Figure 2 shows two exemplary subsets; the first subset shows no clustering, whereas the second is affected by a strong clustering into two groups with no measurements inbetween to support the correlation. Although the correlation coefficient ( $r=0.79$ ) suggests a good correlation, the cluster analysis reveals that two well-separated air masses were measured. Such a subset is excluded from our analysis as the above-mentioned rejection criterion is fulfilled.

In general, our approach differs from the "classical" straightforward approach in that the diagnosed correlations are by definition limited to temporally and spatially coherent events. The enhancement ratios detected with our approach mainly characterize the mean partitioning of acetone and $\mathrm{CO}$ 
sources in the boundary layer on a regional scale. The spread of these source regions depends on the time the analysed air parcel spends in the boundary layer before it is released into the free and upper troposphere. Therefore, one could interpret the correlations derived from our approach as "eventbased" EnRs, whereby the "event" is the release of an individual air parcel out of the boundary layer into the free troposphere. In contrast to our analysis, non-coherent correlations detected in former studies will often mirror spatial (e.g. latitudinal) gradients of acetone and $\mathrm{CO}$, respectively, or imply differences of the trace gas composition of different air masses, but not enhancement ratios that characterize pollution sources and the chemical processing between emission in the boundary layer and sampling in the upper troposphere. For this reason, we believe that our approach is best suited for the analysis of source patterns with tropospheric EnRs.

In Fig. 3, the differences between the two approaches and fit algorithms are illustrated based on the data of 17 selected flights. The flights were chosen in such a way that larger overlaps of data were kept at a minimum. The diversity of the event-based EnRs, ranging from 1.3 to $77.2 \mathrm{ppt} \mathrm{ppb}^{-1}$, is clearly visible. Furthermore, it is shown that initial averaging over the total data (classical approach) instead of averaging over the individual EnRs of coherent events makes a difference. The mean of the individual EnRs (18.6 ppt ppb $\left.{ }^{-1}\right)$ is a factor of 1.9 larger than the slope of the classical approach $\left(9.8 \mathrm{ppt} \mathrm{ppb}^{-1}\right)$. In addition, the EnR of the Williamson-York fit $\left(9.8 \mathrm{pptppb}^{-1}\right)$ is smaller than the one of the standard least-squares fit $\left(11.2 \mathrm{ppt} \mathrm{ppb}^{-1}\right)$, as the former puts (more) weight on the small VMRs due to their lower uncertainties. Less weight is put on the large VMRs, in particular the acetone VMRs, as they have larger uncertainties than the $\mathrm{CO}$ VMRs.

\subsection{Emission inventories}

In this study, we use surface emission data from different inventories made available in the ECCAD (Emissions of atmospheric Compounds \& Compilation of Ancillary Data) database (Granier et al., 2013) of the French Atmospheric Chemistry Data Centre ESPRI (formerly Ether; http://eccad. sedoo.fr/). The objective is to derive the total acetone flux from the boundary layer into the upper troposphere for different regions and compare this flux with the acetone source strengths derived from the enhancement ratios and $\mathrm{CO}$ inventory data. Ideally, we would have preferred to use inventory data of exactly the same years for which CARIBIC data were used in this study (2006-2008; 2012-2015), but not all data in the ECCAD database is yet available for the full period. Therefore, we chose the last 6 years with complete data coverage (2005-2010) as reference period. This period has a similar duration as the CARIBIC periods and at least covers the first CARIBIC data period. Except for biomass burning emissions, there is currently only one possible inventory for each source type for the given period. Hence, anthropogenic

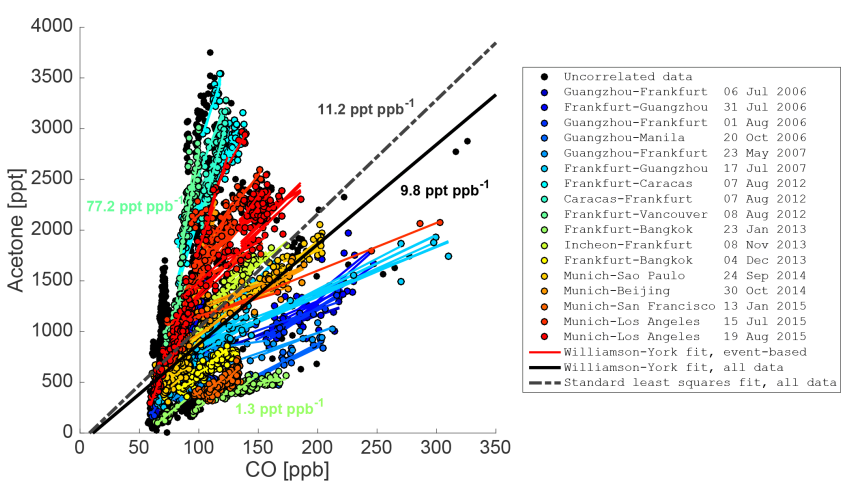

Figure 3. Scatter plot of tropospheric acetone and CO data of $17 \mathrm{se}-$ lected CARIBIC flights. Detected correlations are shown as regression lines plotted in the range of the underlying data. Colour coding denotes to which flight data and correlations belong to. Data, which did not fall into our event-based correlation criteria, are shown as filled black circles regardless of their flight affiliation. The solid black and the grey dashed line represent the results of a WilliamsonYork fit (EnR: $9.8 \mathrm{ppt}^{\mathrm{ppb}} \mathrm{pb}^{-1}$ ) and of a standard least-squares fit (EnR: $11.2 \mathrm{ppt} \mathrm{ppb}^{-1}$ ), respectively, applied to all data of the 17 flights. The minimum, mean and maximum value of the event-based EnRs are 1.3, 18.6 and 77.2, respectively (all values in ppt ppb ${ }^{-1}$ ).

emissions are taken from the MACCity inventory (van der Werf et al., 2006; Lamarque et al., 2010; Granier et al., 2011; Diehl et al., 2012) and biogenic emissions from MEGANMACC (Sindelarova et al., 2014). For biomass burning emissions we decided to use the GFED3 inventory (van der Werf et al., 2010) instead of GFASv1.0 for reasons of easier data handling, as GFED3 data in ECCAD has the same temporal and spatial resolution as MACCity and MEGAN-MACC. Furthermore, Kaiser et al. (2012) found that the budgets of GFED3(.1) are consistent with GFASv1.0.

As we are interested in the total flux of acetone, i.e. primary emissions and secondary production, we also include emission data from the major precursors of acetone and CO. According to Jacob et al. (2002) and Fischer et al. (2012), the three dominant precursors of acetone are propane (13$22 \mathrm{Tg} \mathrm{a}^{-1}$ acetone), higher alkanes (4-7 $\mathrm{Tg} \mathrm{a}^{-1}$ acetone) and monoterpenes (5-6 $\mathrm{Tg} \mathrm{a}^{-1}$ acetone).

In order to estimate the acetone source from propane oxidation, we use propane emission data from MACCity and GFED3 and a molar acetone yield of $72 \%$ (Jacob et al., 2002; Pozzer et al., 2010). For isobutane and isopentane, we use the "butanes and higher alkanes" data of MACCity and calculate the mass proportion of the two species $(5.7 \%$ for isobutane and $9.7 \%$ for isopentane) according to the VOC speciation of Passant (2002) and Calvert et al. (2009). The resulting amount of acetone is derived using the means of the yields suggested by Jacob et al. (2002) and Pozzer et al. (2010), which are $0.96 \mathrm{~mol} \mathrm{~mol}^{-1}$ for isobutane and $0.72 \mathrm{~mol} \mathrm{~mol}^{-1}$ for isopentane. 
For the monoterpenes, we use the emission data for the sum of monoterpenes from MEGAN-MACC (Sindelarova et al., 2014) and the relative contributions provided in Sindelarova et al. (2014) to calculate the emissions of the following individual monoterpene species: $\alpha$-pinene, $\beta$-pinene, limonene, trans- $\beta$-ocimene, myrcene, sabinene and 3 -carene. For each species, we derive mean acetone yields based on the available literature. Here, we consider the two main degradation processes of monoterpenes, reaction with $\mathrm{OH}$ and $\mathrm{O}_{3}$, and weight the yields according to the respective reaction rates (i.e. to the importance of the reaction with regard to all degradation processes). All considered yields and calculations are provided as a supplement.

For the secondary production of $\mathrm{CO}$, we only consider precursors with an annual global contribution of more than $25 \mathrm{Tg}$ CO according to Duncan et al. (2007) and an atmospheric lifetime shorter than that of acetone, i.e. isoprene, methanol, monoterpenes, $\left(\geq C_{4}\right)$ alkanes, $\left(\geq C_{3}\right)$ alkenes and ethene. The respective $\mathrm{CO}$ production yields are taken from the same study and do not account for loss of intermediate trace gases by deposition, which might over-predict the contribution from longer-lived precursors (Duncan et al., 2007). As uncertainties are not provided for all yields and emission inventory fluxes, we refrain from performing a comprehensive uncertainty analysis. However, considerable uncertainties might exist and estimates based on these data have to be taken with care. In our analysis, at least the statistical uncertainties of fluxes are strongly reduced by averaging over large regions and time periods.

\section{Results and discussions}

\subsection{Temporal evolution of EnR between emission and sampling}

For the CARIBIC measurements in the UT, it is important to consider the possible temporal evolution of the EnR, because transport timescales and typical tropospheric lifetimes of acetone and $\mathrm{CO}$ are of a comparable range. So far, the combined influence of dilution and chemical transformation on acetone-CO EnRs has not been addressed in previous studies. In order to better assess their impact, we first examine the temporal evolution of EnRs from a theoretical point of view. We apply a simple one-box model, in which the box represents the volume of the plume at time $t=0$. Whereas the plume expands with time, the considered box volume is held constant to take dilution into account. The temporal evolution of the mixing ratio of a compound $X$ inside the plume can then be approximated by (McKeen and Liu, 1993; McKeen et al., 1996)

$$
\begin{aligned}
\frac{\mathrm{d}[X]_{\text {plume }}}{\mathrm{d} t} & =-L_{X}[X]_{\text {plume }}-D\left([X]_{\text {plume }}-[X]_{\text {bgnd }}\right) \\
& +P_{Z, X}[Z]_{\text {plume }},
\end{aligned}
$$

where $L_{X}$ is the overall chemical loss rate of $X, D$ is the first-order dilution rate and $P_{Z, X}$ is the production rate of $X$ from the oxidation of the precursor compound $Z$. The overall chemical loss rate $L_{X}$ is the sum of all loss mechanisms, which are for acetone reaction with $\mathrm{OH}$ and photolysis $\left(L_{\mathrm{Ac}}=k_{\mathrm{Ac}}[\mathrm{OH}]+J_{\mathrm{Ac}}\right)$ and for $\mathrm{CO}$ reaction with $\mathrm{OH}\left(L_{\mathrm{CO}}=k_{\mathrm{CO}}[\mathrm{OH}]\right)$. As the lifetimes of both species are at least weeks, we simply assume constant reaction and dilution rates over the considered time period. Consequently, we apply daily averaged photolysis rates obtained from the tropospheric ultraviolet and visible radiation model (TUV version 5.0; Madronich and Flocke, 1999; Madronich et al., 2010), which uses the quantum yields for acetone by Blitz et al. (2004), and monthly mean $\mathrm{OH}$ concentrations from Spivakovsky et al. (2000). The $\mathrm{OH}$ reaction rates and uncertainties thereof are taken from the latest recommendations of the IUPAC (International Union of Pure and Applied Chemistry) Task Group on Atmospheric Chemical Kinetic Data Evaluation (Atkinson et al., 2004, 2006). The latter are reported to be $\sim 20 \%$. The same was assumed for the acetone photolysis rate (see Neumaier et al., 2014).

As we are interested in the evolution of $[X]_{\text {plume }}(t)$, we need to integrate Eq. (5), which is impeded by the additional time-dependent variable $[Z]_{\text {plume }}$. We show the following steps without the production term $P_{Z, X}[Z]_{\text {plume }}$ in order to derive an analytical solution. However, in the examples given in Fig. 4, we have solved the full equation numerically including $P_{Z, X}[Z]_{\text {plume }}$, by progressively calculating the changes of $[X]_{\text {plume }}$ and $[Z]_{\text {plume }}$ at hourly intervals, which are short compared to the net reaction rates. Integration of Eq. (5) without the production term $P_{Z, X}[Z]_{\text {plume }}$ leads to

$$
\begin{aligned}
{[X]_{\text {plume }}(t) } & =\left([X]_{\text {plume }, t=0}-\frac{D}{L_{X}+D}[X]_{\text {bgnd }}\right) e^{-\left(L_{X}+D\right) t} \\
& +\frac{D}{L_{X}+D}[X]_{\text {bgnd }} .
\end{aligned}
$$

Since the function does not consider the quasi-equilibrium of the background, it allows for unphysical low mixing ratios in the plume ([X] $\left.]_{\text {plume }}<[X]_{\text {bgnd }}\right)$. Thus, Eq. (6) is only valid for times

$0<t<t_{\max }=\frac{\ln \left(\frac{[X]_{\text {plume }, t=0}}{[X]_{\text {bgnd }}}\left(1+\frac{D}{L_{X}}\right)-\frac{D}{L_{X}}\right)}{L_{X}+D}$.

Placing Eq. (6) into the definition of EnR in Eq. (1) leads to the time-dependent function:

$$
\begin{aligned}
& \operatorname{EnR}(t)= \\
& \quad\left([X]_{\text {plume }, t=0}-\frac{D}{L_{X}+D}[X]_{\text {bgnd }}\right) e^{-\left(L_{X}+D\right) t}-\frac{L_{X}}{L_{X}+D}[X]_{\text {bgnd }} \\
& \left([Y]_{\text {plume }, t=0}-\frac{D}{L_{Y}+D}[Y]_{\text {bgnd }}\right) e^{-\left(L_{Y}+D\right) t}-\frac{L_{Y}}{L_{Y}+D}[Y]_{\text {bgnd }}
\end{aligned}
$$




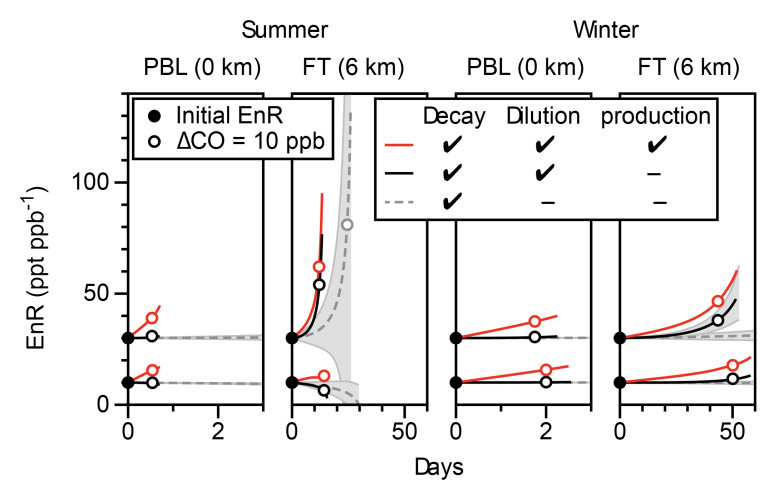

Figure 4. Evolution of acetone-CO enhancement ratios (EnRs) in the mid-latitudinal planetary boundary layer (PBL) and free troposphere (FT) for summer and winter in the Northern Hemisphere calculated numerically (full equation including production term). In the grey dashed lines, only chemical decay of acetone and $\mathrm{CO}$ is considered. In the solid black lines dilution is considered in addition. The red lines represent the EnR evolution if acetone is additionally produced by the oxidation of propane. For selected curves, the range of uncertainty is exemplarily shown in light grey colour. The terminating condition for the EnR calculation is a CO enhancement of $5 \mathrm{ppb}$. The open circles indicate an $\mathrm{CO}$ enhancement of $10 \mathrm{ppb}$. The underlying rates and concentrations are given in Table 5 .

In the case of no chemical processing $\left(L_{X}=L=0\right)$ or if $L_{X}, L_{Y} \ll D$, Eq. (8) simplifies to

$\operatorname{EnR}=\frac{[X]_{\text {plume }, t=0}-[X]_{\text {bgnd }}}{[Y]_{\text {plume }, t=0}-[Y]_{\text {bgnd }}}=$ const.,

i.e. in contrast to the ratio $[X]_{\text {plume }} /[Y]_{\text {plume }}$, the EnR remains constant as long as the plume mixes into the same background. In turn, any temporal change of EnR points to chemical processing inside the plume. However, as soon as chemical decomposition takes place, the assumption $L_{X}=L_{Y}=0$ used in Eq. (9) is no longer valid and the combined impact of both chemical transformation and dilution has to be taken into account in the model.

In contrast to most previous studies, we consider both processes in our model and exclude the background reservoir from any chemical degradation (quasi-steady-state), as changes in the total balance of all sources and sinks are negligible on these short timescales. Based on the evaluation of our model, we find that the direction of change of EnR without secondary production not only depends on the chemical lifetimes of $X$ and $Y$, as stated in former studies, but also strongly depends on the initial concentrations of $X$ and $Y$ relative to their background (see Eq. 8). If the enhancement of $X$ approaches zero faster than the enhancement of $Y$, the EnR decreases and ultimately becomes zero. For the opposite case, the EnR increases and tends towards infinity when approaching the singularity caused by the denominator.

In Fig. 4, the temporal evolution for two initial EnR values at different conditions (season, atmospheric layers and sec- ondary production of acetone) is illustrated. For reasons of clarity, the range of uncertainty based on the uncertainties of the main reaction rates is provided only for selected curves. The underlying mixing ratios and rates are given in Table 5 . The free-tropospheric background concentrations are derived from CARIBIC data (see also Fig. 7). For the PBL, we use estimates based on year-round measurements in Minnesota ( $\mathrm{Hu}$ et al., 2013), California (Schade and Goldstein, 2006) and at Mace Head, Ireland (Novelli et al., 2003). The plume enhancements are scaled according to the selected EnR values. The chemical degradation rates are calculated as described above for $44^{\circ} \mathrm{N}, 1000 \mathrm{hPa}(\mathrm{PBL})$ and $500 \mathrm{hPa}(\mathrm{FT})$ for January (winter) and July (summer). The dilution rates are taken from Table 4 except for the FT in winter, for which we estimate a dilution rate due to the lack of available data. Propane volume mixing ratios are estimated using data from Pozzer et al. (2010), Lewis et al. (2013) and Baker et al. (2014).

In the PBL, EnR (without secondary production) hardly changes until dissolution of the plume, as dilution is the dominant loss process and the approximation used in Eq. (9) is valid. Taking the dilution rates (Table 5) as best estimate, our initially applied enhancements ratios will be completely dissolved in the PBL within less than 1 day in summer and 3 days in winter. Consequently, it is very likely that emissions of different adjacent sources may have mixed before the release into the free troposphere. This means that the free-tropospheric EnR as observed during IAGOSCARIBIC flights will largely reflect a mean value representing the release of regionally well-mixed PBL air into the troposphere and not the emission ratios of single point sources of acetone and $\mathrm{CO}$. In other words, the mixing in the PBL ensures that air masses released into the free troposphere have a specific signature that on average represents the general proportion of acetone and $\mathrm{CO}$ emissions within a certain radius. As already noted in Sect. 3.4, the spread of this source region depends on the residence time of the air mass in the PBL. Furthermore, the footprint is not restricted to sources that simultaneously emit both acetone and $\mathrm{CO}$, but includes sources emitting only acetone or $\mathrm{CO}$ and also secondary production from precursors, if the residence time in the PBL is long compared to their lifetime.

As we are interested in the pure signature to assess the sources, the question arises as to how long the unaltered EnR is conserved in the free troposphere. The examples given in Fig. 4 clearly show that the EnR changes stronger and faster in summer due to shorter lifetimes. In any case, changes become largest in aged plumes, in which the $\mathrm{CO}$ enhancements in the denominator of the EnR become small. As the EnR tends towards infinity when the denominator converges towards zero, the $\mathrm{CO}$ enhancement is more sensitive than the acetone enhancement and, therefore, better suited, e.g., to define the dissolution of the plume. In Fig. 4, we use a $\mathrm{CO}$ enhancement of $5 \mathrm{ppb}$ as dissolution criterion for the calculated evolution of EnRs. In the given examples for the free troposphere in summer, the change of EnR is as high as $\sim 300 \%$ at 
Table 5. Mixing ratios, chemical loss and dilution rates used for the simulation of the temporal evolution of acetone-CO EnRs shown in Fig. 4.

\begin{tabular}{|c|c|c|c|c|c|}
\hline & & \multicolumn{2}{|c|}{ Summer } & \multicolumn{2}{|c|}{ Winter } \\
\hline & & PBL & FT & PBL & FT \\
\hline \multirow{3}{*}{ Background [ppb] } & Acetone & 2.0 & 0.6 & 0.5 & 0.3 \\
\hline & $\mathrm{CO}$ & 100 & 70 & 150 & 80 \\
\hline & Propane & 0.1 & 0.1 & 1.0 & 0.2 \\
\hline \multirow{3}{*}{ Enhancement [ppb] } & Acetone & \multicolumn{4}{|c|}{$4.2 / 2.0$} \\
\hline & $\mathrm{CO}$ & \multicolumn{4}{|c|}{$140 / 200$} \\
\hline & Propane & \multicolumn{4}{|c|}{0.5} \\
\hline \multirow{3}{*}{$\begin{array}{l}\text { Chemical degradation rate }\left[\mathrm{d}^{-1}\right] \\
\text { (lifetime [weeks]) }\end{array}$} & Acetone & $\begin{array}{r}0.029 \pm 0.004 \\
(5.0 \pm 0.7)\end{array}$ & $\begin{array}{r}0.049 \pm 0.007 \\
(2.9 \pm 0.4)\end{array}$ & $\begin{array}{r}0.002 \pm 0.000 \\
(82.9 \pm 11.8)\end{array}$ & $\begin{array}{r}0.004 \pm 0.001 \\
(37.0 \pm 5.2)\end{array}$ \\
\hline & $\mathrm{CO}$ & $\begin{array}{r}0.026 \pm 0.005 \\
(5.5 \pm 1.1)\end{array}$ & $\begin{array}{r}0.039 \pm 0.008 \\
(3.6 \pm 0.7)\end{array}$ & $\begin{array}{r}0.002 \pm 0.000 \\
(94.0 \pm 18.8)\end{array}$ & $\begin{array}{r}0.003 \pm 0.001 \\
(49.3 \pm 9.9)\end{array}$ \\
\hline & Propane & $\begin{array}{r}0.111 \pm 0.023 \\
(1.3 \pm 0.3)\end{array}$ & $\begin{array}{r}0.154 \pm 0.031 \\
(0.9 \pm 0.2)\end{array}$ & $\begin{array}{r}0.005 \pm 0.001 \\
(26.7 \pm 5.3)\end{array}$ & $\begin{array}{r}0.009 \pm 0.002 \\
\quad(15.2 \pm 3.0)\end{array}$ \\
\hline Dilution rate $\left[\mathrm{d}^{-1}\right]$ & & 4.80 & 0.10 & 1.44 & 0.05 \\
\hline
\end{tabular}

Table 6. Mean and median values of EnR frequency distributions and centre of the fitted Gaussian distributions.

\begin{tabular}{llr}
\hline Season & & $\begin{array}{r}\text { Slope/EnR } \\
{\left[\mathrm{ppt} \mathrm{ppb}^{-1}\right]}\end{array}$ \\
\hline \multirow{3}{*}{ JJAS } & Arithmetic mean $\pm \sigma$ & $27.2 \pm 17.0$ \\
& Median & 22.9 \\
& Gaussian line centre $\pm \sigma$ & $19.3 \pm 12.9$ \\
& Number of correlated/ & $4747 / 12896$ \\
& all measurements & \\
\hline \multirow{3}{*}{ DJFM } & Arithmetic mean $\pm \sigma$ & $11.6 \pm 7.2$ \\
& Median & 9.4 \\
& Gaussian line centre $\pm \sigma$ & $8.5 \pm 3.5$ \\
& Number of correlated $/$ & $4137 / 10311$ \\
& all measurements & \\
\hline
\end{tabular}

the time of dissolution, strongly depending on the initial $\mathrm{CO}$ enhancement and the presence of secondary acetone production. As we do not have information about the actual age of the plumes observed in CARIBIC and thus cannot correct for the temporal changes, we limit our analysis to plumes with a $\mathrm{CO}$ enhancement greater than $10 \mathrm{ppb}$ (more specifically, 10 times the mean measurement uncertainty of $\mathrm{CO}$; see Sect. 3.4). We are aware that this threshold (open circles in Fig. 4) represents a trade-off between maximizing the number of detected correlations to achieve good statistics and minimizing the consideration of aged plumes with EnRs, which have been changed by chemistry and dilution to such an extent that conclusions about the source signature

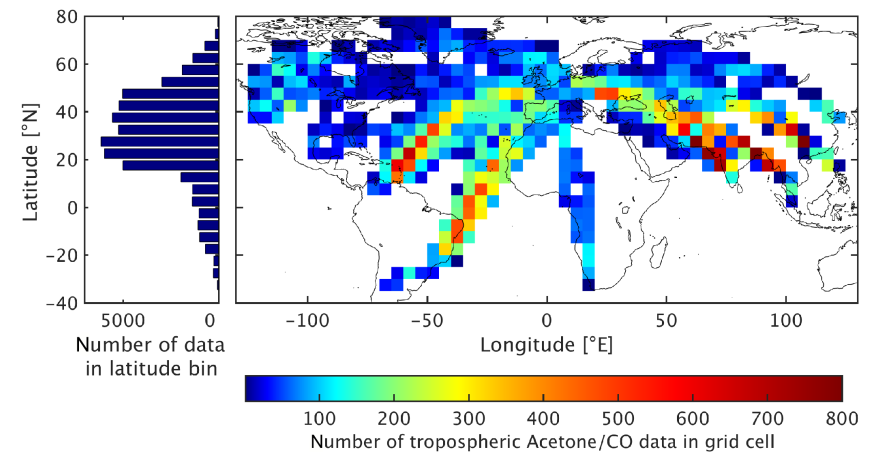

Figure 5. Latitudinal (left) and geographical distribution (right) of simultaneous tropospheric acetone and $\mathrm{CO}$ measurements in the time periods February 2006-December 2008 and March 2012-July 2015. Grid cells without data are left bank.

are not possible. This problem and the sensitivity of results with regard to the chosen threshold are further addressed in Sect. B of the Appendix.

In former studies, the observation of high acetone-CO EnRs was often associated with secondary production of acetone in the plume (Wisthaler et al., 2002; Holzinger et al., 2005). Propane is primarily considered as a precursor in this context, as it is co-emitted by biomass burning and assumed to be the dominant precursor of acetone (Jacob et al., 2002; Fischer et al., 2012). If considering this source of acetone in our model, the loss of acetone is partly compensated and may lead to an increase in EnR. For plumes in the PBL, the temporal increase in EnR is therefore an indicator for secondary 
production of acetone. In the free troposphere, the situation is more complex and our model predicts an increase of EnR in three of four cases even without the presence of propane, although we have to admit that the range of uncertainty is very large in one case. Especially in summer, when the curves of the higher EnR with and without secondary production do not differ significantly, it seems to be hardly feasible to distinguish between the different reasons of increasing EnRs.

As mentioned earlier, another reason for possible changes in EnR between emission and measurement is the subsequent mixing with different backgrounds (e.g. Mauzerall et al., 1998; Yokelson et al., 2013). Equation (8) is only valid as long as the terms $[X]_{\text {bgnd }}$ and $[Y]_{\text {bgnd }}$ are constant. Whenever the background mixing ratios change, e.g. the plume enters the free troposphere, the EnR becomes larger under the condition

$$
\begin{aligned}
& \left([X]_{\text {bgnd,old }}-[X]_{\text {bgnd,new }}\right) \\
& \quad>\operatorname{EnR}_{\text {old }}\left([Y]_{\text {bgnd,old }}-[Y]_{\text {bgnd,new }}\right)
\end{aligned}
$$

and smaller for the reverse inequality. Figure 1 illustrates this common scenario and the resulting change of the slope of the mixing line.

\subsection{Observation of EnR within IAGOS-CARIBIC}

\subsubsection{Temporal and spatial distribution of data}

The analysis of acetone-CO EnR relies on the availability of the simultaneous measurement of acetone and $\mathrm{CO}$ in the troposphere. At the time of this study, tropospheric acetone data were available for 105 CARIBIC flights between 20 February 2006 and 13 December 2008 and for 109 CARIBIC flights between 6 March 2012 and 16 July 2015. The gap is due to a larger modification of the instrument and subsequent re-certification. As shown in Fig. 5, about $90 \%$ of simultaneous tropospheric acetone and $\mathrm{CO}$ measurements were carried out in the Northern Hemisphere, mainly in the subtropics and mid-latitudes along the routes between Germany and Caracas/Bogota, Sao Paolo, Chennai, Bangkok and Guangzhou/Hong Kong. Although IAGOS-CARIBIC flights to North America took place frequently, mainly stratospheric air was sampled due to the lower tropopause heights there. In order to obtain statistically reliable results, we focus on the subtropics and mid-latitudes.

\subsubsection{Frequency distribution of EnR}

In Fig. 6, frequency distributions of the acetone-CO EnR are compared for summer (JJAS) and winter (DJFM). We extended the commonly used months JJA (June-July-August) and DJF (December-January-February) by 1 month to improve the statistics. Compared to the airborne and ground observations by others (see Tables 2-3), the CARIBIC observations provide a surprisingly clear picture. In order to quantify the distributions, we use Gaussian profiles (see parame-

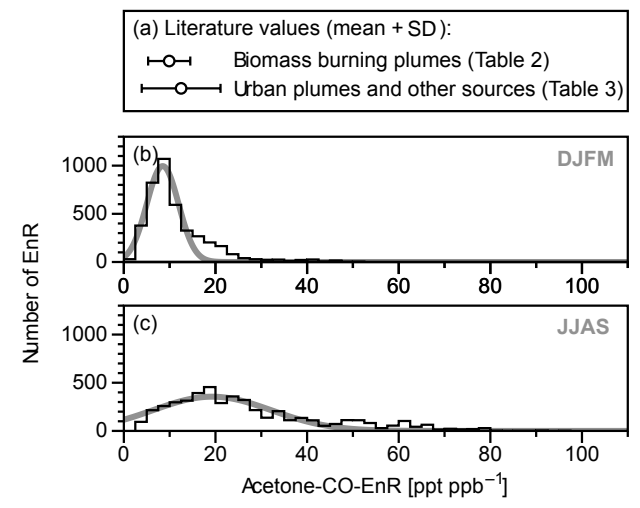

Figure 6. Comparison of (a) the mean literature values for biomass burning plumes and for plumes of other origin with the distribution of EnR observed with CARIBIC in the Northern Hemisphere subtropics and mid-latitudes $\left(23.5-66.5^{\circ} \mathrm{N}\right)$ in (b) winter (DJFM) and (c) summer (JJAS). The grey lines represent Gaussian curves fitted to the histograms. The values of the most important statistical variables describing the distributions are given in Table 6 .

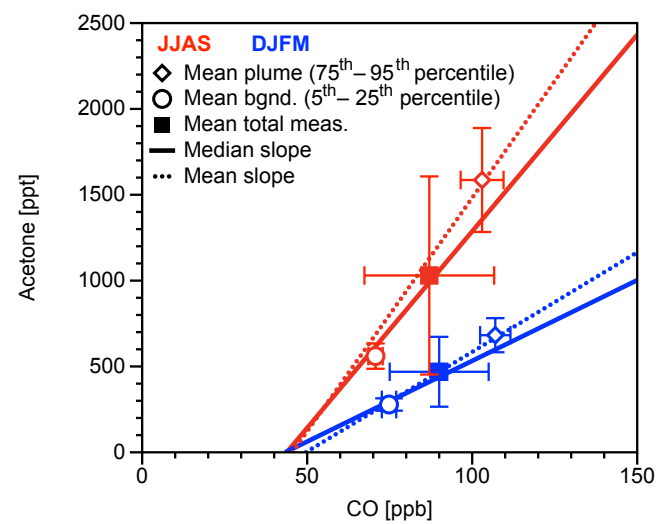

Figure 7. Regression lines for summer (red) and winter (blue), using mean slope (solid line) and median slope (dotted line) given in Table 6. The filled squares represent the mean VMRs of the total measurements, whereas the open circles (diamonds) are the mean of all values lying in the 5th to 25 th (75th and 95th) percentile, respectively.

ters in Table 6). In winter, the approximated Gaussian profile has its centre at $8.5 \mathrm{ppt} \mathrm{ppb}^{-1}$ (Full Width at Half Maximum $\left.(\mathrm{FWHM})=8.2 \mathrm{ppt} \mathrm{ppb}^{-1}\right)$. Thus, the centre is slightly lower than the mean literature values derived for plumes with and without biomass burning influence $\left(9.9\right.$ and $12.5 \mathrm{ppt} \mathrm{ppb} \mathrm{pb}^{-1}$, respectively; see Table 2-3), but both values lie within the $1 \sigma$ range. It is clear that the real distribution differs from a normal distribution, as $33 \% / 21 \%$ of the EnRs exceed the $1 \sigma / 2 \sigma$ range of the Gaussian profile. This asymmetry is probably a result of the sampling of aged plumes as discussed in Sect. 4.1.

In summer, observed EnRs are on average $\sim 2.3$ times larger compared to winter. The centre of the Gaussian pro- 
file (19.3 ppt ppb $\left.{ }^{-1}\right)$ is higher than the mean literature values, but again the values lie within the $1 \sigma$ range. The FMHW of the Gaussian profile is even $\sim 3.7$ times greater $\left(\sim 30.4 \mathrm{ppt} \mathrm{ppb}^{-1}\right)$, reflecting the larger natural variability in summer. As in winter, the real distribution of CARIBIC EnRs is shifted towards larger values (mean: $27.2 \mathrm{ppt} \mathrm{ppb}^{-1}$ ). About $30 \% / \sim 16 \%$ of the EnRs exceed the $1 \sigma / 2 \sigma$ range of the Gaussian profile. The great majority of high EnRs in summer was sampled in air masses measured above or originating from North America (see next section).

To identify the reason for the considerable seasonal variation of the acetone-CO EnR in the upper troposphere, we plot the regression lines for the mean and median parameters as derived from our EnR distributions (Table 6) alongside the VMRs of the total measurements (Fig. 7). It becomes clear that the factor of $\sim 2.3$ between summer and winter EnR is mainly the consequence of the considerable seasonality of acetone. The mean CO VMRs between JJAS and DJFM differ by only $6 \%$, simply as the CO maximum and minimum in the UT occur in March-April and September-October, respectively (Zahn et al., 2002; Zbinden et al., 2013; Petetin et al., 2016; Osman et al., 2016).

\subsection{Regional differences in EnR and comparison with emission inventories}

In this subsection, we use sample location and 5-day ECMWF backwards trajectories calculated every $3 \mathrm{~min}$ along the flight track (van Velthoven, 2016) to assign EnR to selected source regions. If a correlation is found in a subset of data (see Sect. 3.4), the derived EnR is assigned to each acetone-CO data pair of the subset and to the closest 5-day back trajectory thereof.

According to our box model (see grey dashed line in Fig. 4), in the free troposphere chemical decay (no dilution) does not significantly alter the EnR within 5 days; in the given examples, changes are below $5 \%$ in summer and below $1 \%$ in winter. Therefore, we assign each EnR to the full path of the corresponding 5-day back trajectory, which is given with a temporal resolution of $1 \mathrm{~h}$. In practice, this means that for each hourly waypoint of the trajectory, the assigned EnR is duplicated and the coordinates of the sample location are exchanged by the ones of the waypoint. This domain-filling technique is also known as trajectory mapping and has been applied elsewhere for similar in situ datasets (Stohl et al., 2001; Osman et al., 2016). In Fig. 8, the resulting geographical distribution and frequency of EnRs duplicated this way is shown for a $5^{\circ} \times 5^{\circ}$ grid. We are aware that back trajectories have limited reliability; however, random trajectory errors should be negligible in our case, with respect to the large number of trajectory-mapped EnRs.

The assignment of EnRs to source regions is done as follows. In a first step, longitude-latitude boxes are defined for the regions of interest. Here, we focus on the four regions North America, Europe, East Asia and Southeast Asia as de-

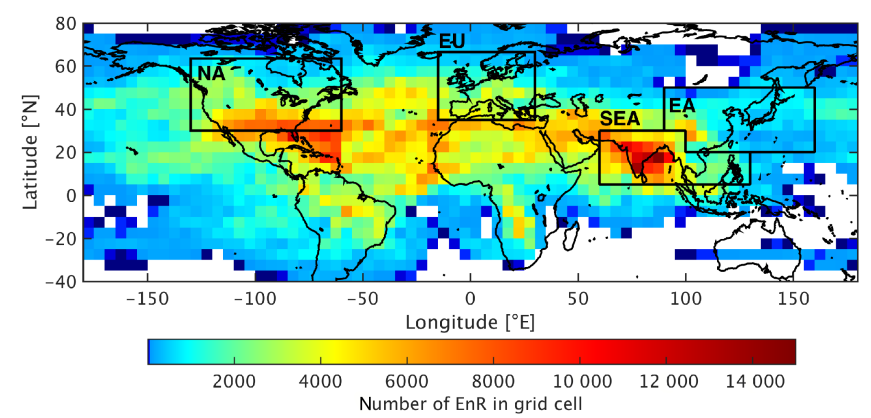

Figure 8. Geographical distribution of EnRs duplicated along the waypoints of the assigned 5-day back trajectories. Grid cells without data are left bank. Four areas of interest (rectangles) are considered: North America (NA), Europe (EU), Southeast Asia (SEA) or East Asia (EA).

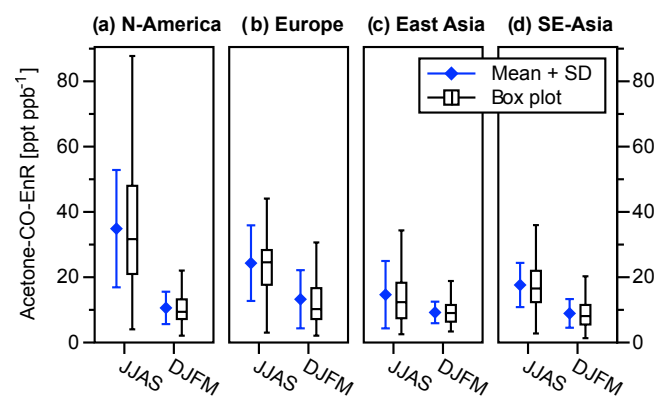

Figure 9. Mean and standard deviation (SD) (blue) and box plots (black) of EnR summer (JJAS) and winter (DJFM) distributions for four selected regions as shown in Fig. 8. In the underlying distributions, individual EnRs have been duplicated along the hourly waypoints of the assigned 5-day back trajectories to consider the residence time of the samples above the region. The numbers of individual, unique EnRs as well as percentages related to the total number of EnRs are given in Table 7.

picted in Fig. 8. All EnRs with coordinates inside a box, including the duplicates from the trajectory mapping, are assigned to the corresponding region. This means, that an EnR is initially assigned to a region regardless of whether the trajectory passed through the box only for $1 \mathrm{~h}$ or the entire 5 days. However, when it comes to averaging over all EnRs of a certain region, we distinguish between such cases. For this purpose, we do not eliminate the duplicates created by the trajectory mapping. Consequently, an EnR associated with a trajectory passing the box only for $1 \mathrm{~h}$, is represented only once in the regional subset, whereas an EnR with a trajectory staying in the box for 5 days is represented in the subset 120 $(=5 \times 24 \mathrm{~h})$ times. When averaging over EnRs of a certain region, this naturally leads to a weighting based on the trajectory's residence time above the region. We refrained from an altitude requirement, as not all transport processes are represented by single trajectory calculations (e.g. convection; see Stohl et al., 2002). Furthermore, in single trajectory calculations infinitesimally small air parcels are assumed (e.g. Stohl 
Table 7. Numbers and percentages of individual EnRs for different months and regions. EnRs are associated with a specific region, when the assigned trajectory passes through the box of the region. For the assignment it does not matter whether only one waypoint or the entire trajectory lies inside the box. Assignment to multiple regions occurs, when the trajectory crosses more than one box. The boxes of the respective regions are indicated in Fig. 8.

\begin{tabular}{|c|c|c|c|c|c|c|c|c|c|c|}
\hline \multirow[b]{2}{*}{ JJAS } & \multicolumn{2}{|c|}{ North America } & \multicolumn{2}{|c|}{ Europe } & \multicolumn{2}{|c|}{ East Asia } & \multicolumn{2}{|c|}{ Southeast Asia } & \multicolumn{2}{|c|}{ Global } \\
\hline & 3060 & $15 \%$ & 1218 & $6 \%$ & 1272 & $6 \%$ & 992 & $5 \%$ & 6535 & $32 \%$ \\
\hline DJFM & 1725 & $8 \%$ & 1688 & $8 \%$ & 685 & $3 \%$ & 2255 & $11 \%$ & 7686 & $37 \%$ \\
\hline Other months & 2085 & $10 \%$ & 1344 & $7 \%$ & 1343 & $7 \%$ & 2262 & $11 \%$ & 6431 & $31 \%$ \\
\hline All months & 6870 & $33 \%$ & 4250 & $21 \%$ & 3300 & $16 \%$ & 5509 & $27 \%$ & 20652 & $100 \%$ \\
\hline
\end{tabular}

et al., 2002), whereas the volumes of sampled air masses are extended. For these reasons, we believe that even though a trajectory passes a region at high altitudes, there is certain likelihood that the sampled air mass had contact with convected air masses from the boundary layer of the underlying region. As the probability of such an incident increases with time, weighting according to the trajectory's residence time over the region makes most sense to us.

In Fig. 9, the weighted-mean EnRs and box plots are shown for each source region and the months JJAS and DJFM, respectively. The numbers of the underlying, unique (i.e. non-duplicated) EnRs and percentages of the total number of EnRs are given in Table 7. Please note that single EnRs can be assigned to multiple regions, when the trajectories pass through more than one region. The best coverage is archived for North America (33\%) and Southeast Asia ( $27 \%$ ), which is also why we focus on these regions in the following.

North America stands out with the highest EnRs observed in IAGOS-CARIBIC. In summer, the median EnR (31.7 $\left.\mathrm{ppt} \mathrm{ppb}^{-1}\right)$ is $\sim 3.4$ times larger than in winter $\left(9.4 \mathrm{ppt} \mathrm{ppb}^{-1}\right)$ and the interquartile range is even $\sim 5.4$ times larger compared to winter. The significantly higher EnR in summer compared to winter can be explained by the following reasons: (i) the much stronger biogenic source strength in summer, (ii) the more frequent sampling of younger (acetone-rich) plumes due to strong convection and (iii) the faster increase in EnR due to shorter chemical lifetimes (see Sect. 4.1 and Fig. 4). The seasonality is less pronounced (in descending order) above Europe, Southeast Asia and East Asia. In contrast to the mean EnRs, individual low EnRs are observed throughout the year in all regions, as can be seen from the overlap of the lower whiskers in Fig. 9. Low EnR in summer might be an indication of rapidly ascended plumes from sources with low acetone-CO emission ratios, such as smouldering fires and other incomplete combustion processes (see Table 1).
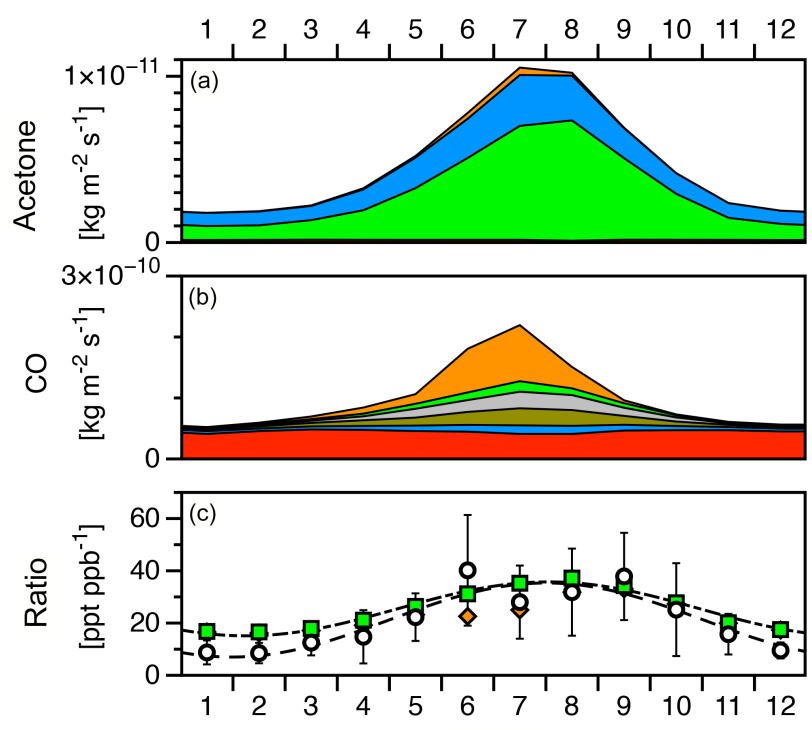

\begin{tabular}{|c|c|c|}
\hline & & \\
\hline $\begin{array}{l}\text { Primary emissions: } \\
\text { biomass burning (BB) } \\
\text { biogenic } \\
\text { anthropogenic }\end{array}$ & $\begin{array}{l}\text { Secondary production: } \\
\text { methanol } \\
\text { isoprene } \\
\text { others }^{1}\end{array}$ & $\begin{array}{l}\text { Ratios: } \\
\text { O EnR (this study) } \\
\text { TER, BB excluded } \\
\diamond \text { TER; BB included }\end{array}$ \\
\hline
\end{tabular}

Figure 10. North American emission rates of (a) acetone and (b) $\mathrm{CO}$ according to the ECCAD inventory database, averaged over the time period 2005-2010. (c) Mean EnRs derived from IAGOSCARIBIC measurements are compared to ECCAD total emissions volume ratios (TERs) of acetone and $\mathrm{CO}$ with and without consideration of biomass burning (BB). The dashed lines show sinusoidal functions fitted to the monthly means of EnR and TER (biomass burning excluded). ${ }^{1}$ Includes propane, isobutane, isopentane, seven monoterpene species and methylbutenol as precursors of acetone and ethene, $\left(\geq \mathrm{C}_{4}\right)$ alkanes, $\left(\geq \mathrm{C}_{3}\right)$ alkenes and monoterpenes as precursors of $\mathrm{CO}$.

\subsubsection{Emission rates in North America}

As a next logical step towards identifying the cause for the high EnRs over North America in summer, we consider emission estimates given in inventories for different source types (e.g. anthropogenic, biogenic and biomass burning emissions; see Sect. 3.5). This classification enables an assessment of the influence of the different sources on the respec- 

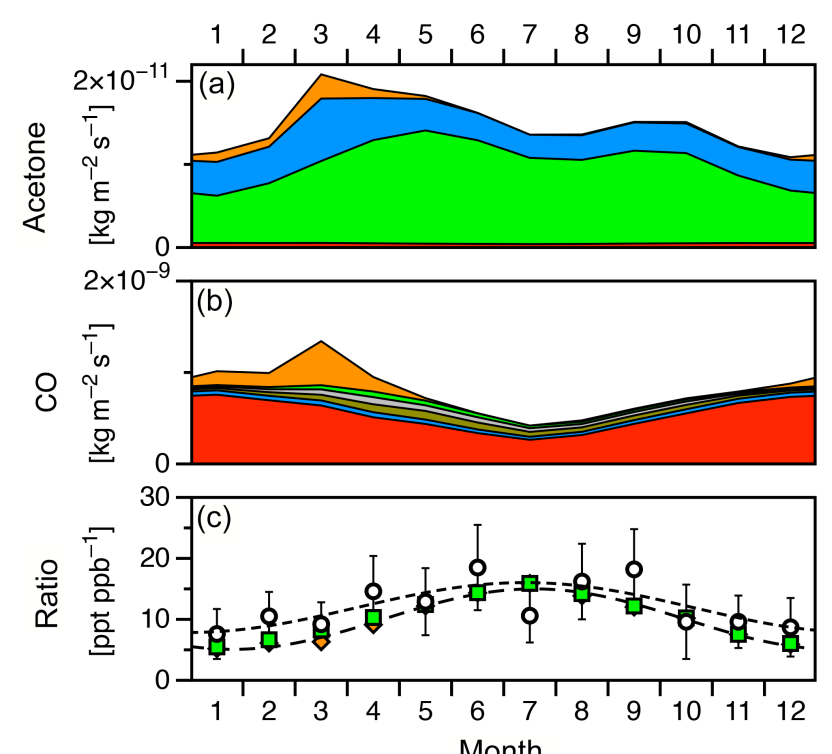

\begin{tabular}{|c|c|c|}
\hline $\begin{array}{l}\text { Primary emissions: } \\
\text { biomass burning (BB) } \\
\text { biogenic } \\
\text { anthropogenic }\end{array}$ & $\begin{array}{l}\text { Secondary production: } \\
\text { methanol } \\
\text { isoprene } \\
\text { others }^{1}\end{array}$ & $\begin{array}{l}\text { Ratios: } \\
\text { O EnR (this study) } \\
\square \text { TER; BB excluded } \\
\diamond \text { TER; BB included }\end{array}$ \\
\hline
\end{tabular}

Figure 11. Southeast Asian emission rates of (a) acetone and (b) CO according to the ECCAD database for the time period 20052010. (c) Volume ratio of total emissions of acetone and CO displayed for three different scenarios and compared to EnR derived from IAGOS-CARIBIC in situ data. A sinusoidal function (dashed line) is fitted to the monthly means of EnR and total emissions volume ratio (TER), respectively (see Fig. 10). ${ }^{1}$ Includes propane, isobutane, isopentane and seven monoterpene species as precursors of acetone and ethene, $\left(\geq \mathrm{C}_{4}\right)$ alkanes, $\left(\geq \mathrm{C}_{3}\right)$ alkenes and monoterpenes as precursors of $\mathrm{CO}$.

tive total source, which helps us to interpret the observed seasonal variability in EnR. Therefore, we derive the volume ratio of total emissions of acetone and CO. For reasons of simplicity, we name it total emissions volume ratio, abbreviated TER. It is defined as

$\mathrm{TER}=\frac{M_{\mathrm{CO}}}{M_{\mathrm{Ac}}} \cdot \frac{\sum_{i} S_{\mathrm{Ac}, i}}{\sum_{i} S_{\mathrm{CO}, i}}$

where $M$ is the molar mass of the respective compound and $S$ is the emission flux of the individual source averaged over the reference time period 2005-2010.

In Fig. 10, the seasonal variation of (a) the acetone emission rates, (b) the $\mathrm{CO}$ emission rates and (c) the monthly means of TERs and EnRs are shown. The emissions of acetone and $\mathrm{CO}$ are in phase with maxima in summer and minima in winter, but the seasonal amplitude for acetone is much stronger due to the larger proportion of biogenic emissions. In Fig. 10c, we compare the inventory-based TER (with and without the consideration of biomass burning emissions) with the monthly means of IAGOS-CARIBIC EnR identi- fied during the two time periods 2006-2008 and 2012-2015. A direct comparison only makes sense if the considered CARIBIC EnRs are not significantly altered by dilution and chemical processing. As discussed in Sect. 4.1, the effects of these processes are not negligible and for this reason, we limit our analysis to events with a $\mathrm{CO}$ enhancement of at least 10 times the measurement uncertainty of $\mathrm{CO}(\sim 10 \mathrm{ppb})$. In the ideal case, this restriction ensures that CARIBIC EnRs primarily reflect the chemical signature of the source regions.

The highest EnR are found in June and September $\left(\sim 40 \mathrm{ppt} \mathrm{ppb}^{-1}\right)$ with a temporary decline in-between. On the first view, this seems to be an insignificant feature, but there are some further observations that identify biomass burning as the most likely reason:

1. We observed elevated acetonitrile VMRs during this time period. In $\sim 53 \%$ of the air masses with correlated acetone and $\mathrm{CO}$ measurements, we find acetonitrile VMRs greater than $200 \mathrm{ppt}$, which according to Sakamoto et al. (2015) presents a threshold for the detection of biomass burning plumes. EnRs in June appear to be unaffected by biomass burning, supported by the consistently lower acetonitrile VMR level $(<200 \mathrm{ppt})$ compared to the following month.

2. The EnR decline is also apparent in TER with a shift of 1 month ahead, which can be attributed to biomass burning (orange diamonds in Fig. 10c). The reason lies in the low acetone-CO emission ratio of boreal forest fires of 1.6-3.0 ppt ppb ${ }^{-1}$ (see Table 1). Warneke et al. (2006) found various plumes attributed to biomass burning during flights along the US east coast in July and August 2004 and concluded that $30 \%$ of the CO enhancement is related to forest fires in Alaska and Canada, which is in good agreement with the emission inventory data $(\sim 32 \%)$. We therefore assume that the lower EnRs in July and August $\left(\sim 30 \mathrm{ppt} \mathrm{ppb}^{-1}\right)$ are related to a then larger influence of biomass burning.

In July, we find a mean ( \pm standard deviation) EnR of $(28.0 \pm 14.0) \mathrm{ppt} \mathrm{ppb}^{-1}$, which is comparable to the ones found during aircraft campaigns over eastern Canada, i.e. by de Reus et al. (2003) during STREAM (Stratosphere Troposphere Experiment by Airborne Measurements) in July 1998 (24.4 ppt $\mathrm{ppb}^{-1}$ ) and by Singh et al. (1994) during ABLE3B (Arctic Boundary Layer Experiment) in July and August 1990 (30 ppt ppb $\left.{ }^{-1}\right)$. The higher variability in the IAGOSCARIBIC EnR is presumably due to the large regional and annual variations in emissions, which are only resolved when considering local correlations over a longer time interval such as in IAGOS-CARIBIC.

\subsubsection{Estimation of North American acetone source}

Emission and enhancement ratios are frequently used to estimate global acetone emissions from biomass burning (e.g. 
Holzinger et al., 1999, 2005; Jacob et al., 2002; Wisthaler et al., 2002; Singh et al., 2004; van der Werf et al., 2010; Akagi et al., 2011). Singh et al. (2010) denoted that this top-down approach is often useful in assessing the accuracy of emission inventories that are generally derived from bottom-up data. Since we did not restrict our analysis to BB plumes, the IAGOS-CARIBIC EnRs should reflect the total acetone source. In order to derive the total acetone flux $S_{\mathrm{Ac}}$ from our observations, the mass-corrected CARIBIC EnR is multiplied by the total flux of $\mathrm{CO}$ derived from inventories:

$S_{\mathrm{Ac}}=\mathrm{EnR} \cdot \frac{M_{\mathrm{Ac}}}{M_{\mathrm{CO}}} \cdot \sum_{i} S_{\mathrm{CO}, i}$.

For North America, we estimate a mean annual flux of (53 \pm 27$) 10^{-13} \mathrm{~kg} \mathrm{~m}^{-2} \mathrm{~s}^{-1}$ corresponding to total emissions of $(6.0 \pm 3.1) \mathrm{Tg} \mathrm{a}^{-1}$. This is in very good agreement with the bottom-up estimate of $5.8 \mathrm{Tg} \mathrm{a}^{-1}$, which we derived by summing up the mean acetone emissions given in the sourcespecific emission inventories (see Sect. 3.5).

In contrast, $\mathrm{Hu}$ et al. (2013) determined a North American acetone source of $10.9 \mathrm{Tg} \mathrm{a}^{-1}$ from tall-tower measurements and inverse modelling, consisting of $5.5 \mathrm{Tg}$ from biogenic sources and $5.4 \mathrm{Tg}$ from anthropogenic sources. Whereas the biogenic source is similar to our estimate because the a priori source is equal $(4.8 \mathrm{Tg})$, they assume a much higher anthropogenic source based on the US EPA NEI 2005 (NEI-05) inventory ( $12 \%$ primary, $88 \%$ secondary). We note that anthropogenic emissions of acetone, propane and CO in NEI05 are $\sim 3, \sim 2$ and $\sim 1.5$ times higher, respectively, than the ones given by the MACCity inventory used in this study. Several studies stated that NEI-05 overestimates anthropogenic emissions of $\mathrm{CO}$ and other species (Brioude et al., 2011, 2013; Kim et al., 2013; Li et al., 2015), whereas Stein et al. (2014) reported that the anthropogenic emissions of CO in MACCity underestimate the source in Northern Hemisphere industrialized countries in winter. The latter would be in accordance with our observation of lower EnR compared to TER in winter in Fig. 10c. A larger anthropogenic acetone source would push EnRs in the opposite direction and is not supported by IAGOS-CARIBIC EnR results. Further investigations are required to resolve the discrepancy between the above-mentioned model result of $\mathrm{Hu}$ et al. (2013) and the bottom-up and top-down estimates.

\subsubsection{Emission rates in Southeast Asia}

In this section, we focus our EnR-based approach to assess regional acetone sources to the Southeast Asia region. Because of its increasing role in global air pollution and the current shortage of in situ studies regarding the emissions of this region, Southeast Asia stands out as a highly interesting region (Jaffe et al., 1999; de Laat et al., 2001; Lelieveld et al., 2001, 2015). The rapid industrialization is accompanied by widespread biomass burning resulting in a significantly different pollution source profile compared to North Amer- ica (e.g. de Laat et al., 2001). Here we focus on the region of Southeast Asia (including Pakistan, India, Bangladesh, Bhutan, Myanmar, Thailand, Laos, Cambodia, Vietnam and the Philippines) as defined in van der Werf et al. (2006). In this region, the acetone emission fluxes given in the inventories (Fig. 11a) are on average $\sim 3$ times higher than in North America and show a different seasonality due to the different (i.e. mainly wet tropical and humid subtropical) climate. Emissions of CO (Fig. 11b) are mainly assigned to anthropogenic sources throughout the year, showing a maximum in March due to biomass burning emissions and a minimum in July.

In Fig. 11c, TER and IAGOS-CARIBIC EnR are plotted for comparison. As for North America, both are in the same range and show the same seasonal variation when fitting a sinusoidal function to the monthly TER and EnR, but EnR (annual mean: $12.2 \mathrm{ppt} \mathrm{ppb}^{-1}$ ) are on average $\sim 3 \mathrm{ppt}_{\mathrm{ppb}}^{-1}$ higher than TER (annual mean: $9.2 \mathrm{ppt}_{\mathrm{ppb}}^{-1}$ ). EnR values derived from the research aircraft campaign INDOEX (INDian Ocean EXperiment) conducted over the Indian Ocean in February-March 1999 are even higher than mean CARIBIC EnRs for February and March $\left(9.7 \mathrm{ppt} \mathrm{ppb}^{-1}\right)$. De Reus et al. (2003) found a mean EnR of 21.6 and $16.2 \mathrm{ppt} \mathrm{ppb}^{-1}$ when integrating over all flights in the free troposphere and in the marine boundary layer air, respectively. De Gouw et al. (2001) derived an EnR of $14 \mathrm{ppt} \mathrm{ppb}^{-1}$ using data from the same campaign, but averaged acetone and $\mathrm{CO}$ values for level flight tracks before applying the correlation analysis. The results are consistent with the EnRs of $13.4-17.2 \mathrm{ppt} \mathrm{ppb}^{-1}$ found in individual plumes in the marine boundary layer over the Indian Ocean (Reiner et al., 2001; Wisthaler et al., 2002). The reasons for the high EnRs in INDOEX compared to the mean TER of Southeast Asia $\left(\sim 7.7 \mathrm{pptppb}^{-1}\right)$ and the mean CARIBIC EnR $\left(9.7 \mathrm{ppt} \mathrm{ppb}^{-1}\right)$ can be manifold. Besides this comprehensive campaign in 1999, little data have been published on acetone emissions in this region. Based on the IAGOSCARIBIC EnR and inventory data for $\mathrm{CO}$ and its precursors, we derive a mean ( \pm standard deviation) acetone flux of $(185 \pm 80) 10^{-13} \mathrm{~kg} \mathrm{~m}^{-2} \mathrm{~s}^{-1}$ corresponding to total emissions of $(4.8 \pm 2.1) \mathrm{Tg} \mathrm{a}^{-1}$. Langford et al. (2010) observed a mean acetone flux of $(33 \pm 181) 10^{-13} \mathrm{~kg} \mathrm{~m}^{-2} \mathrm{~s}^{-1}$ above a tropical rainforest in Malaysia in 2008, whereas Karl et al. (2004) reported a mean midday flux of $250 \times 10^{-13} \mathrm{~kg} \mathrm{~m}^{-2} \mathrm{~s}^{-1}$ above a tropical rainforest in Costa Rica. All three fluxes are in the same range, but hardly comparable, because of the different spatial and temporal scopes of the measurements. Whereas the in situ flux measurements at individual locations reflect local conditions, the mean CARIBIC EnRs are representative of extended heterogeneous source regions and also capture secondary acetone production during transport. The inventory data for acetone and its precursors suggests a mean annual flux of $149 \times 10^{-13} \mathrm{~kg} \mathrm{~m}^{-2} \mathrm{~s}^{-1}$ and an annual source of $3.7 \mathrm{Tg} \mathrm{a}^{-1}$ 
for Southeast Asia, which is lower than our estimates, but well within the standard deviation.

\section{Summary and conclusions}

In this study, we give a major update on enhancement ratios of acetone and $\mathrm{CO}$ in the upper troposphere. We present a new method to detect coherent correlations that are physically more meaningful than correlations based on spatially or temporally distant measurements. We apply this method to the IAGOS-CARIBIC dataset of acetone and CO and utilize the concept of enhancement ratios for interpretation. In former studies, free-tropospheric acetone-CO enhancement ratios were often compared directly with emission ratios of individual sources, although enhancement ratios are only equivalent to the emission ratio when measured at the source. For EnRs higher than the ERs, the authors assumed secondary production of acetone in the plume. We show, using a box model, that an increase in EnR is not inevitably caused by secondary production of acetone, but strongly depends on the initial quantities of acetone and CO in the plume. Dilution rates from other studies indicate that common enhancements are rapidly mixed in the PBL and rather contribute to the PBL background than being directly transported into the free troposphere. We conclude that an uplift of these air masses leads to tropospheric EnRs that can be seen as a chemical signature of the boundary layer air, therefore rather reflecting larger regional source patterns than distinct emissions from single point sources. As the sources vary by season, we investigate the seasonality of EnR and find that in the Northern Hemisphere mid-latitudes they are on average 2.3 times larger in summer than in winter. Given the coverage and representativeness of the IAGOS-CARIBIC dataset, it is also possible to investigate regional differences in EnR and its seasonality. We compare the seasonality of EnR observed over North America, Europe, East Asia and Southeast Asia and find the same behaviour for all four regions, but with varying degrees. We assume that these differences are mainly caused by regional differences in acetone and $\mathrm{CO}$ sources and therefore enable the comparison of EnR with emission estimates of inventories. The monthly ratios of the total acetone and CO bottom-up source estimates lie well within the standard deviation of mean EnR observed over the respective region and show the same seasonal course as EnR. We calculate regional acetone fluxes by using well-constrained $\mathrm{CO}$ emission data and monthly averaged EnR. For North America, we estimate a mean annual acetone flux of $53 \times 10^{-13} \mathrm{~kg} \mathrm{~m}^{-2} \mathrm{~s}^{-1}$ and for Southeast Asia $185 \times 10^{-13} \mathrm{~kg} \mathrm{~m}^{-2} \mathrm{~s}^{-1}$, reflecting the dominance of biogenic acetone emissions that are larger in tropical to subtropical Southeast Asia. With our EnRbased approach, it will be also possible to estimate regional acetone fluxes for other regions in the future. First preliminary evaluations for tropical South America show that EnRs are significantly lower than the monthly total emission ratios derived from inventories, except for months with high biomass burning emissions. It could well be that the large biogenic source of the Amazon rainforest does not provide sufficiently strong regional gradients (plumes) to be captured by our event-based detection algorithm. However, the detected EnRs might be related to biomass burning or polluted air masses from the highly populated coastal regions. Further investigations, e.g. analysis of other tracers or evaluation of our box model adapted to the particular conditions, are necessary to understand this potential discrepancy. In addition, further measurements over this region would be of great value. We conclude that free-tropospheric EnR data with a large spatial and temporal coverage are a powerful tool to investigate the regional and seasonal differences in sources, to estimate the total acetone flux of specific regions and potentially to assess the quality of acetone emission inventories.

\section{Data availability}

The CARIBIC data and relevant information are available from the CARIBIC website (http: //www.caribic-atmospheric.com) upon signing the CARIBIC data protocol and by contacting the CARIBIC coordinator (andreas.zahn@kit.edu). The trajectory data are available from the website http://projects.knmi.nl/campaign_support/CARIBIC/ (van Velthoven, 2016). The underlying emission inventory data are available via the ECCAD database (http://eccad.sedoo.fr/) (Granier et al., 2013) upon signing the data protocol. 


\section{Appendix A: Detailed description of emission data in Fig. 10}

The strongest source of acetone in North America is direct biogenic emission with an annual mean of $\sim 31 \times 10^{-13} \mathrm{~kg} \mathrm{~m}^{-2} \mathrm{~s}^{-1}$ and a strong maximum in July/August $\left(\sim 70 \times 10^{-13} \mathrm{~kg} \mathrm{~m}^{-2} \mathrm{~s}^{-1}\right)$. The second largest source is secondary production from precursors. Jacob et al. (2002) and Fischer et al. (2012) assumed that propane is by far the dominant precursor of acetone on a global scale followed by higher alkanes and monoterpenes. Here, we consider propane, isobutane and isopentane, seven individual monoterpene species and methylbutenol (MBO) as precursors of acetone.

Methylbutenol is emitted by pine trees native exclusively to North America (e.g. Harley et al., 1998; Kim et al., 2010) and is therefore considered as a regional source. As MBO emission data are not available in the ECCAD database, we scale the monthly monoterpene surface emissions in a way that annual MBO emissions equal the estimate of $2.2 \mathrm{Tg}$ by Guenther et al. (2012). Based on the available literature, we derive and apply a mean molar acetone yield of 0.46 for the oxidation of MBO. When assuming an instantaneous conversion on the ground (which is justified for the shorterlived precursors), MBO oxidation leads to an annual mean acetone production of $\sim 5.6 \times 10^{-13} \mathrm{~kg} \mathrm{~m}^{-2} \mathrm{~s}^{-1}$, whereas the oxidation of propane $\left(\sim 2.7 \times 10^{-13} \mathrm{~kg} \mathrm{~m}^{-2} \mathrm{~s}^{-1}\right)$, higher alkanes $\left(\sim 3.4 \times 10^{-13} \mathrm{~kg} \mathrm{~m}^{-2} \mathrm{~s}^{-1}\right)$ and of monoterpenes $\left(\sim 3.6 \times 10^{-13} \mathrm{~kg} \mathrm{~m}^{-2} \mathrm{~s}^{-1}\right)$ produce considerably less acetone.

Secondary production is the largest in summer $\left(\sim 14 \times 10^{-13} \mathrm{~kg} \mathrm{~m}^{-2} \mathrm{~s}^{-1}, \quad \sim 4.1 \times 10^{-13} \mathrm{~kg} \mathrm{~m}^{-2} \mathrm{~s}^{-1}\right.$, $\sim 3.4 \times 10^{-13} \mathrm{~kg} \mathrm{~m}^{-2} \mathrm{~s}^{-1}$ and $\sim 9.1 \times 10^{-13} \mathrm{~kg} \mathrm{~m}^{-2} \mathrm{~s}^{-1}$ ), because of the much higher light- and temperature-driven release of biogenic VOCs and additional propane emissions from boreal forest fires. In contrast, direct anthropogenic emissions of acetone (originating from solvent use, chemical manufacturers and car exhaust) are spread uniformly throughout the year with $\sim 1.6 \times 10^{-13} \mathrm{~kg} \mathrm{~m}^{-2} \mathrm{~s}^{-1}$ and account only for a small percentage of the source $(\sim 2 \%$ in summer and $\sim 9 \%$ in winter). As we do not account for potential losses (e.g. deposition) of precursors before their conversion, but assume instantaneous conversion, the given emission strengths likely represent upper limits.

Carbon monoxide emissions (Fig. 10b) show a very different source composition. Direct anthropogenic emission is overall the strongest source and is evenly distributed throughout the year with a mean flux of $\sim 4.5 \times 10^{-11} \mathrm{~kg} \mathrm{~m}^{-2} \mathrm{~s}^{-1}$. Biomass burning is the second largest individual source and limited to the burning season (the summer months) with the relative source contribution exceeding $30 \%$ and fluxes of $\sim 9 \times 10^{-11} \mathrm{~kg} \mathrm{~m}^{-2} \mathrm{~s}^{-1}$. However, we must stress that BB emissions vary considerably from year to year and there have been years (e.g. 2004; see Turquety et al., 2007) in which emissions were 2-3 times higher than the average over the period 2005-2010. As already ascertained for acetone, biogenic emissions (primary and secondary) are the highest in summer and account for $\sim 45 \%$ of the North American CO source in this season. Hudman et al. (2008) found an even higher contribution of $\sim 56 \%$ from the oxidation of biogenic VOCs in the summer of 2004, but, firstly, they limited their study to the contiguous United States, where no biomass burning occurred and, secondly, considered a higher $\mathrm{CO}$ yield for isoprene ( 0.45 per $\mathrm{C}$ atom, compared to 0.2 per $\mathrm{C}$ atom found by Duncan et al. (2007) as global average and applied in our study). However, we must point out that the production rate strongly depends on local $\mathrm{NO}_{x}$ concentrations (Miyoshi et al., 1994) and a higher yield may be reasonable for the USA. In contrast to acetone, primary biogenic CO fluxes are relatively low $\left(\sim 0.6 \times 10^{-11} \mathrm{~kg} \mathrm{~m}^{-2} \mathrm{~s}^{-1}\right)$ and the secondary production from isoprene and methanol oxidation (mean annual flux: $\sim 2.2 \times 10^{-11} \mathrm{~kg} \mathrm{~m}^{-2} \mathrm{~s}^{-1}$ ) dominates.

\section{Appendix B: Sensitivity of results for North America with regard to the $\mathrm{CO}$ enhancement requirement}

In Sect. 4.1, we motivate our choice to restrict the analysis to EnR with a $\mathrm{CO}$ enhancement greater than 10 times the measurement uncertainty of $\mathrm{CO}$, which is on average close to $10 \mathrm{ppb}$. To demonstrate the latter, we repeat the analysis done in Sect. 4.3.2 for North America with a threshold of exactly $10 \mathrm{ppb}$ CO enhancement. In Table B1, the results are compared with the previous analysis. The annual acetone source of $(6.1 \pm 3.1) \mathrm{Tg}$ is in excellent agreement with the $(6.0 \pm 3.1) \mathrm{Tg}$ derived when using 10 times the measurement uncertainty of $\mathrm{CO}$ as threshold.

In a second reanalysis, we use a threshold of $15 \mathrm{ppb}$ to test the sensitivity of the result to a higher threshold (results, see Table B1). Increasing the threshold to such an $\mathrm{CO}$ enhancement reduces the dataset for North America by $\sim 75 \%$, leading to the situation that there is not enough data for November and December, although North America is the region with the best coverage (see Table 7).

The mean of the monthly EnR decreases from 21.3 to $18.4 \mathrm{ppt} \mathrm{ppb}^{-1}$, which can be explained as follows. The exclusion of events with $\mathrm{CO}$ enhancements of 10-15 ppb puts more emphasis on the events with high-CO enhancements, but the high-CO enhancements are not completely compensated by high-acetone enhancements; i.e. the EnRs of this subset are lower. Nevertheless, the means for all three requirements are still in the standard deviations of each other.

When changing the threshold to significantly lower CO enhancements, the monthly mean EnRs increase. However, in such a situation it becomes impossible to our mind to distinguish between an increase caused by shifting the weight of certain EnRs and an increase related to the temporal evolution of EnRs, which we discussed in Sect. 4.1. Consequently, we can only investigate the sensitivity in respect to higher $\mathrm{CO}$ 
Table B1. Results of three different cut-off requirements (top row) applied to the dataset for North America. For each month and cut-off requirement, the number of unique EnRs $(n)$, the mean $\mathrm{EnR}$ and standard deviation in $\mathrm{ppt}_{\mathrm{ppb}}{ }^{-1}$ and the resulting acetone source $\left(S_{\mathrm{Ac}}\right)$ in $\mathrm{Tg}$ are provided. The means and standard deviations for all months (last row) are based on the monthly values.

\begin{tabular}{|c|c|c|c|c|c|c|c|c|c|}
\hline \multirow[b]{2}{*}{ Month } & \multicolumn{3}{|c|}{$\Delta \mathrm{CO}>10 \sigma$} & \multicolumn{3}{|c|}{$\Delta \mathrm{CO}>10 \mathrm{ppb}$} & \multicolumn{3}{|c|}{$\Delta \mathrm{CO}>15 \mathrm{ppb}$} \\
\hline & $n$ & $\begin{array}{r}\text { Mean }+ \text { SD } \\
\text { EnR }\end{array}$ & $S_{\mathrm{Ac}}$ & $\begin{array}{r}n \\
\text { EnR }\end{array}$ & Mean + SD & $\begin{array}{r}S_{\mathrm{Ac}} \\
\text { EnR }\end{array}$ & $n$ & Mean + SD & $S_{\mathrm{Ac}}$ \\
\hline 1 & 543 & $8.8 \pm 4.6$ & 0.1 & 465 & $9.0 \pm 4.9$ & 0.1 & 115 & $6.5 \pm 6.2$ & 0.1 \\
\hline 2 & 339 & $8.5 \pm 3.9$ & 0.1 & 278 & $8.7 \pm 4.1$ & 0.1 & 154 & $9.0 \pm 5.0$ & 0.1 \\
\hline 3 & 744 & $12.5 \pm 4.9$ & 0.2 & 688 & $12.6 \pm 4.9$ & 0.2 & 163 & $11.8 \pm 5.3$ & 0.2 \\
\hline 4 & 1427 & $14.8 \pm 10.2$ & 0.3 & 1400 & $14.8 \pm 10.3$ & 0.3 & 362 & $12.4 \pm 8.0$ & 0.2 \\
\hline 5 & 167 & $22.2 \pm 9.1$ & 0.5 & 167 & $22.2 \pm 9.1$ & 0.5 & 50 & $21.0 \pm 5.8$ & 0.5 \\
\hline 6 & 568 & $40.2 \pm 21.2$ & 1.3 & 565 & $40.1 \pm 21.2$ & 1.3 & 51 & $29.8 \pm 2.7$ & 1.0 \\
\hline 7 & 434 & $28.0 \pm 14.0$ & 1.1 & 434 & $28.0 \pm 14.0$ & 1.1 & 239 & $28.4 \pm 13.8$ & 1.1 \\
\hline 8 & 1102 & $31.8 \pm 16.7$ & 1.0 & 1102 & $31.8 \pm 16.7$ & 1.0 & 361 & $24.9 \pm 11.0$ & 0.7 \\
\hline 9 & 956 & $37.8 \pm 16.7$ & 0.7 & 722 & $40.2 \pm 17.2$ & 0.8 & 100 & $21.1 \pm 10.1$ & 0.4 \\
\hline 10 & 397 & $25.2 \pm 17.8$ & 0.4 & 371 & $24.8 \pm 17.9$ & 0.4 & 53 & $34.2 \pm 15.3$ & 0.5 \\
\hline 11 & 94 & $15.7 \pm 7.7$ & 0.2 & 77 & $16.0 \pm 8.6$ & 0.2 & 0 & - & \\
\hline 12 & 99 & $9.5 \pm 3.1$ & 0.1 & 52 & $9.3 \pm 3.2$ & 0.1 & 4 & $3.7 \pm 0.2$ & 0.0 \\
\hline All & 6870 & $21.3 \pm 11.3$ & $6.0 \pm 3.1$ & 6321 & $21.5 \pm 11.6$ & $6.1 \pm 3.1$ & 1652 & $18.4 \pm 10.3$ & $4.8 \pm 1.9$ \\
\hline
\end{tabular}

enhancements. Thresholds higher than $15 \mathrm{ppb}$ are not feasible with regard to the number of such events in our dataset.

\section{Appendix C: Detailed description of emission data in}

Fig. 11

Biogenic emission dominates throughout the year with a minimum in January $\left(\sim 64 \times 10^{-13} \mathrm{~kg} \mathrm{~m}^{-2} \mathrm{~s}^{-1}\right)$ and a maximum in May $\left(\sim 154 \times 10^{-13} \mathrm{~kg} \mathrm{~m}^{-2} \mathrm{~s}^{-1}\right)$. Biomass burning emissions peak in the late dry season (January-April) and contribute to an annual maximum of acetone emissions in March $\left(\sim 208 \times 10^{-13} \mathrm{~kg} \mathrm{~m}^{-2} \mathrm{~s}^{-1}\right)$ being twice as large as the maximum acetone flux of North America.

For the same reason, $\mathrm{CO}$ emissions (Fig. 11b) peak in March. However, besides the large contribution of biomass burning $(37 \%)$, other anthropogenic sources make up the greatest part $(48 \%)$ of the total $\mathrm{CO}$ flux $\left(\sim 131 \times 10^{-11} \mathrm{~kg} \mathrm{~m}^{-2} \mathrm{~s}^{-1}\right)$, which is 7 times larger than the maximum CO flux of North America. Over the year as a whole, anthropogenic emissions account for $\sim 70 \%$ of the total Southeast Asian CO source and are responsible for the seasonal variation with minima in summer and maxima in winter. The largest anthropogenic $\mathrm{CO}$ source is residential (bio-)fuel combustion for cooking and heating, followed by emissions from the industry and transport sector (e.g. Ohara et al., 2007; Li et al., 2017). Biogenic emissions of CO and its precursors peak in April-May $\left(\sim 22 \times 10^{-11} \mathrm{~kg} \mathrm{~m}^{-2} \mathrm{~s}^{-1}\right)$, but only account for $\sim 28 \%$ of the total emission flux during this time and $\sim 18 \%$ of the total annual source. 


\section{The Supplement related to this article is available online at doi:10.5194/acp-17-1985-2017-supplement.}

Acknowledgements. The authors wish to thank Lufthansa, Lufthansa Technik and all CARIBIC partners for their ongoing support of the IAGOS-CARIBIC laboratory. We especially acknowledge D. Scharffe for supplying the CO data and A. RautheSchöch for supplying the merge files. We thank T. Gehrlein, S. Heger, C. Koeppel, A. Petrelli, D. Scharffe and S. Weber for their commitment in operating the CARIBIC container. We acknowledge the NCAR Atmospheric Chemistry Division (ACD) for providing the TUV Radiation Model. We thank the Centre National d'Etudes Spatiales (CNES) and the Centre National de la Recherche Scientifique (CNRS) - Institut National des Sciences de l'Univers (INSU) for distributing the emission inventory data in the ECCAD database. ECCAD is part of the ESPRI Data centre (formerly Ether) and the emission database of the GEIA (Global Emissions InitiAtive) project, which are gratefully acknowledged.

The article processing charges for this open-access publication were covered by a Research

Centre of the Helmholtz Association.

Edited by: A. Pozzer

Reviewed by: two anonymous referees

\section{References}

Akagi, S. K., Yokelson, R. J., Wiedinmyer, C., Alvarado, M. J., Reid, J. S., Karl, T., Crounse, J. D., and Wennberg, P. O.: Emission factors for open and domestic biomass burning for use in atmospheric models, Atmos. Chem. Phys., 11, 4039-4072, doi:10.5194/acp-11-4039-2011, 2011.

Akagi, S. K., Craven, J. S., Taylor, J. W., McMeeking, G. R., Yokelson, R. J., Burling, I. R., Urbanski, S. P., Wold, C. E., Seinfeld, J. H., Coe, H., Alvarado, M. J., and Weise, D. R.: Evolution of trace gases and particles emitted by a chaparral fire in California, Atmos. Chem. Phys., 12, 1397-1421, doi:10.5194/acp-12-13972012, 2012.

Andreae, M. O. and Merlet, P.: Emissions of trace gases and aerosols from biomass burning, Global Biogeochem. Cy., 15, 955-966, doi:10.1029/2000GB001382, 2001.

Arnold, S. R., Chipperfield, M. P., and Blitz, M. A.: A threedimensional model study of the effect of new temperaturedependent quantum yields for acetone photolysis, J. Geophys. Res., 110, D22305, doi:10.1029/2005JD005998, 2005.

Arnold, S. R., Methven, J., Evans, M. J., Chipperfield, M. P., Lewis, A. C., Hopkins, J. R., McQuaid, J. B., Watson, N., Purvis, R. M., Lee, J. D., Atlas, E. L., Blake, D. R., and Rappenglück, B.: Statistical inference of $\mathrm{OH}$ concentrations and air mass dilution rates from successive observations of nonmethane hydrocarbons in single air masses, J. Geophys. Res., 112, D10S40, doi:10.1029/2006JD007594, 2007.

Atkinson, R., Baulch, D. L., Cox, R. A., Crowley, J. N., Hampson, R. F., Hynes, R. G., Jenkin, M. E., Rossi, M. J., and Troe, J.:
Evaluated kinetic and photochemical data for atmospheric chemistry: Volume $\mathrm{I}-$ gas phase reactions of $\mathrm{O}_{x}, \mathrm{HO}_{x}, \mathrm{NO}_{x}$ and $\mathrm{SO}_{x}$ species, Atmos. Chem. Phys., 4, 1461-1738, doi:10.5194/acp-41461-2004, 2004.

Atkinson, R., Baulch, D. L., Cox, R. A., Crowley, J. N., Hampson, R. F., Hynes, R. G., Jenkin, M. E., Rossi, M. J., and Troe, J.: Evaluated kinetic and photochemical data for atmospheric chemistry: Volume II - gas phase reactions of organic species, Atmos. Chem. Phys., 6, 3625-4055, doi:10.5194/acp-6-3625-2006, 2006.

Baker, A. K., Traud, S., Brenninkmeijer, C. A. M., Hoor, P., Neumaier, M., Oram, D. E., Rauthe-Schöch, A., Sprung, D., Schloegl, S., Slemr, F., van Velthoven, P. F. J., Wernli, H., Zahn, A., and Ziereis, H.: Pollution patterns in the upper troposphere over Europe and Asia observed by CARIBIC, Atmos. Environ., 96, 245-256, doi:10.1016/j.atmosenv.2014.06.010, 2014.

Blitz, M. A., Heard, D. E., Pilling, M. J., Arnold, S. R., and Chipperfield, M. P.: Pressure and temperature-dependent quantum yields for the photodissociation of acetone between 279 and $327.5 \mathrm{~nm}$, Geophys. Res. Lett., 31, L06111, doi:10.1029/2003GL018793, 2004.

Brenninkmeijer, C. A. M., Crutzen, P., Boumard, F., Dauer, T., Dix B., Ebinghaus, R., Filippi, D., Fischer, H., Franke, H., Frie $\beta$, U., Heintzenberg, J., Helleis, F., Hermann, M., Kock, H. H., Koeppel, C., Lelieveld, J., Leuenberger, M., Martinsson, B. G., Miemczyk, S., Moret, H. P., Nguyen, H. N., Nyfeler, P., Oram, D., O’Sullivan, D., Penkett, S., Platt, U., Pupek, M., Ramonet, M., Randa, B., Reichelt, M., Rhee, T. S., Rohwer, J., Rosenfeld, K., Scharffe, D., Schlager, H., Schumann, U., Slemr, F., Sprung, D., Stock, P., Thaler, R., Valentino, F., van Velthoven, P., Waibel, A., Wandel, A., Waschitschek, K., Wiedensohler, A., Xueref-Remy, I., Zahn, A., Zech, U., and Ziereis, H.: Civil Aircraft for the regular investigation of the atmosphere based on an instrumented container: The new CARIBIC system, Atmos. Chem. Phys., 7, 4953-4976, doi:10.5194/acp-7-4953-2007, 2007.

Brioude, J., Kim, S.-W., Angevine, W. M., Frost, G. J., Lee, S.H., McKeen, S. A., Trainer, M., Fehsenfeld, F. C., Holloway, J. S., Ryerson, T. B., Williams, E. J., Petron, G., and Fast, J. D.: Top-down estimate of anthropogenic emission inventories and their interannual variability in Houston using a mesoscale inverse modeling technique, J. Geophys. Res., 116, D20305, doi:10.1029/2011JD016215, 2011.

Brioude, J., Angevine, W. M., Ahmadov, R., Kim, S.-W., Evan, S., McKeen, S. A., Hsie, E.-Y., Frost, G. J., Neuman, J. A., Pollack, I. B., Peischl, J., Ryerson, T. B., Holloway, J., Brown, S. S., Nowak, J. B., Roberts, J. M., Wofsy, S. C., Santoni, G. W., Oda, T., and Trainer, M.: Top-down estimate of surface flux in the Los Angeles Basin using a mesoscale inverse modeling technique: assessing anthropogenic emissions of $\mathrm{CO}, \mathrm{NO}_{x}$ and $\mathrm{CO}_{2}$ and their impacts, Atmos. Chem. Phys., 13, 3661-3677, doi:10.5194/acp13-3661-2013, 2013

Brito, J.: A Lightweight High-sensitivity Chemical Mass Spectrometer for Organic Compounds, Ph.D. thesis, Karlsruhe Institute for Technology (KIT), 2012.

Brito, J., Wurm, F., Yáñez-Serrano, A. M., de Assunção, J. V., Godoy, J. M., and Artaxo, P.: Vehicular Emission Ratios of VOCs in a Megacity Impacted by Extensive Ethanol Use: Results of Ambient Measurements in São Paulo, Brazil, Environ. Sci. Technol., 49, 11381-11387, doi:10.1021/acs.est.5b03281, 2015. 
Calvert, J., Derwent, R., Orlando, J., Tyndall, G., and Wallington, T.: Mechanisms of Atmospheric Oxidation of the Alkanes, Angew. Chemie Int., 48, 24-27, doi:10.1002/anie.200901202, 2009.

Cantrell, C. A.: Technical Note: Review of methods for linear leastsquares fitting of data and application to atmospheric chemistry problems, Atmos. Chem. Phys., 8, 5477-5487, doi:10.5194/acp8-5477-2008, 2008.

Coheur, P.-F., Herbin, H., Clerbaux, C., Hurtmans, D., Wespes, C., Carleer, M., Turquety, S., Rinsland, C. P., Remedios, J., Hauglustaine, D., Boone, C. D., and Bernath, P. F.: ACE-FTS observation of a young biomass burning plume: first reported measurements of $\mathrm{C}_{2} \mathrm{H}_{4}, \mathrm{C}_{3} \mathrm{H}_{6} \mathrm{O}, \mathrm{H}_{2} \mathrm{CO}$ and PAN by infrared occultation from space, Atmos. Chem. Phys., 7, 5437-5446, doi:10.5194/acp-75437-2007, 2007.

de Gouw, J. A. and Warneke, C.: Measurements of volatile organic compounds in the earth's atmosphere using proton-transferreaction mass spectrometry, Mass Spectrom. Rev., 26, 223-257, doi:10.1002/mas.20119, 2007.

de Gouw, J. A., Warneke, C., Scheeren, H. A., van der Veen, C., Bolder, M., Scheele, M. P., Williams, J., Wong, S., Lange, L., Fischer, H., and Lelieveld, J.: Overview of the trace gas measurements on board the Citation aircraft during the intensive field phase of INDOEX, J. Geophys. Res. Atmos., 106, 28453-28467, doi:10.1029/2000JD900810, 2001.

de Gouw, J. A., Goldan, P. D., Warneke, C., Kuster, W. C., Roberts, J. M., Marchewka, M., Bertman, S. B., Pszenny, A. A. P., and Keene, W. C.: Validation of proton transfer reaction-mass spectrometry (PTR-MS) measurements of gas-phase organic compounds in the atmosphere during the New England Air Quality Study (NEAQS) in 2002, J. Geophys. Res. Atmos., 108, 4682, doi:10.1029/2003JD003863, 2003.

de Laat, A. T. J., de Gouw, J. A., Lelieveld, J., and Hansel, A.: Model analysis of trace gas measurements and pollution impact during INDOEX, J. Geophys. Res. Atmos., 106, 28469-28480, doi:10.1029/2000JD900821, 2001.

de Reus, M., Fischer, H., Arnold, F., de Gouw, J. A., Holzinger, R., Warneke, C., and Williams, J.: On the relationship between acetone and carbon monoxide in different air masses, Atmos. Chem. Phys., 3, 1709-1723, doi:10.5194/acp-3-1709-2003, 2003.

Diehl, T., Heil, A., Chin, M., Pan, X., Streets, D., Schultz, M., and Kinne, S.: Anthropogenic, biomass burning, and volcanic emissions of black carbon, organic carbon, and $\mathrm{SO}_{2}$ from 1980 to 2010 for hindcast model experiments, Atmos. Chem. Phys. Discuss., 12, 24895-24954, doi:10.5194/acpd-12-24895-2012, 2012.

Dixon, J. L., Beale, R., and Nightingale, P. D.: Production of methanol, acetaldehyde, and acetone in the Atlantic Ocean, Geophys. Res. Lett., 40, 4700-4705, doi:10.1002/grl.50922, 2013.

Dufour, G., Szopa, S., Harrison, J. J., Boone, C. D., and Bernath, P. F.: Seasonal variations of acetone in the upper troposphere-lower stratosphere of the northern midlatitudes as observed by ACE-FTS, J. Mol. Spectrosc., 323, 67-77, doi:10.1016/j.jms.2016.02.006, 2016.

Duncan, B. N., Logan, J. A., Bey, I., Megretskaia, I. A., Yantosca, R. M., Novelli, P. C., Jones, N. B., and Rinsland, C. P.: Global budget of CO, 1988-1997: Source estimates and validation with a global model, J. Geophys. Res. Atmos., 112, D22301, doi:10.1029/2007JD008459, 2007.
Elias, T., Szopa, S., Zahn, A., Schuck, T., Brenninkmeijer, C., Sprung, D., and Slemr, F.: Acetone variability in the upper troposphere: analysis of CARIBIC observations and LMDz-INCA chemistry-climate model simulations, Atmos. Chem. Phys., 11, 8053-8074, doi:10.5194/acp-11-8053-2011, 2011.

Everitt, B. S. and Hand, D. J.: Mixtures of normal distributions, in Finite Mixture Distributions, Springer Netherlands, Dordrecht, 25-57, 1981.

Fischer, E. V., Jacob, D. J., Millet, D. B., Yantosca, R. M., and Mao, J.: The role of the ocean in the global atmospheric budget of acetone, Geophys. Res. Lett., 39, L01807, doi:10.1029/2011GL050086, 2012.

Fischer, E. V., Jacob, D. J., Yantosca, R. M., Sulprizio, M. P., Millet, D. B., Mao, J., Paulot, F., Singh, H. B., Roiger, A., Ries, L., Talbot, R. W., Dzepina, K., and Pandey Deolal, S.: Atmospheric peroxyacetyl nitrate (PAN): a global budget and source attribution, Atmos. Chem. Phys., 14, 2679-2698, doi:10.5194/acp-142679-2014, 2014.

Folkins, I. and Chatfield, R.: Impact of acetone on ozone production and $\mathrm{OH}$ in the upper troposphere at high $\mathrm{NO}_{x}$, J. Geophys. Res. Atmos., 105, 11585-11599, doi:10.1029/2000JD900067, 2000.

Granier, C., Bessagnet, B., Bond, T., D’Angiola, A., van der Gon, H., Frost, G. J., Heil, A., Kaiser, J. W., Kinne, S., Klimont, Z., Kloster, S., Lamarque, J.-F., Liousse, C., Masui, T., Meleux, F., Mieville, A., Ohara, T., Raut, J.-C., Riahi, K., Schultz, M. G., Smith, S. J., Thompson, A., Aardenne, J., Werf, G. R., and Vuuren, D. P.: Evolution of anthropogenic and biomass burning emissions of air pollutants at global and regional scales during the 1980-2010 period, Clim. Change, 109, 163-190, doi:10.1007/s10584-011-0154-1, 2011.

Granier, C., Boulanger, D., D’Angiola, A., Darras, S., Liousse, C., Marlière, J.-F., Miéville, A., Paulin, M., Pignot, V., and Zemankova, K.: Access to Emissions Distributions and Related Ancillary Data through the ECCAD database, EGU General Assembly Conference Abstracts, vol. 15, p. 10593, 2013.

Greenberg, J. P., Friedli, H., Guenther, A. B., Hanson, D., Harley, P., and Karl, T.: Volatile organic emissions from the distillation and pyrolysis of vegetation, Atmos. Chem. Phys., 6, 81-91, doi:10.5194/acp-6-81-2006, 2006.

Guenther, A. B., Jiang, X., Heald, C. L., Sakulyanontvittaya, T., Duhl, T., Emmons, L. K., and Wang, X.: The Model of Emissions of Gases and Aerosols from Nature version 2.1 (MEGAN2.1): an extended and updated framework for modeling biogenic emissions, Geosci. Model Dev., 5, 1471-1492, doi:10.5194/gmd-51471-2012, 2012.

Hansel, A. and Wisthaler, A.: A method for real-time detection of PAN, PPN and MPAN in ambient air, Geophys. Res. Lett., 27, 895-898, doi:10.1029/1999GL010989, 2000.

Harley, P., Fridd-Stroud, V., Greenberg, J., Guenther, A., and Vasconcellos, P.: Emission of 2-methyl-3-buten-2-ol by pines: A potentially large natural source of reactive carbon to the atmosphere, J. Geophys. Res. Atmos., 103, 25479-25486, doi:10.1029/98JD00820, 1998.

Harrison, J. J., Humpage, N., Allen, N. D. C., Waterfall, A. M., Bernath, P. F., and Remedios, J. J.: Mid-infrared absorption cross sections for acetone (propanone), J. Quant. Spectrosc. Radiat. Transf., 112, 457-464, doi:10.1016/j.jqsrt.2010.09.002, 2011. 
Holton, J. R., Haynes, P. H., McIntyre, M. E., Douglass, A. R., Rood, R. B., and Pfister, L.: Stratosphere-troposphere exchange, Rev. Geophys., 33, 403-439, doi:10.1029/95RG02097, 1995.

Holzinger, R., Warneke, C., Hansel, A., Jordan, A., Lindinger, W., Scharffe, D. H., Schade, G., and Crutzen, P. J.: Biomass burning as a source of formaldehyde, acetaldehyde, methanol, acetone, acetonitrile, and hydrogen cyanide, Geophys. Res. Lett., 26, 1161-1164, doi:10.1029/1999GL900156, 1999.

Holzinger, R., Williams, J., Salisbury, G., Klüpfel, T., de Reus, M., Traub, M., Crutzen, P. J., and Lelieveld, J.: Oxygenated compounds in aged biomass burning plumes over the Eastern Mediterranean: evidence for strong secondary production of methanol and acetone, Atmos. Chem. Phys., 5, 39-46, doi:10.5194/acp-5-39-2005, 2005.

Hoskins, B. J., McIntyre, M. E., and Robertson, A. W.: On the use and significance of isentropic potential vorticity maps, Q. J. Roy. Meteor. Soc., 111, 877-946, doi:10.1002/qj.49711147002, 1985.

Hu, L., Millet, D. B., Kim, S. Y., Wells, K. C., Griffis, T. J., Fischer, E. V., Helmig, D., Hueber, J., and Curtis, A. J.: North American acetone sources determined from tall tower measurements and inverse modeling, Atmos. Chem. Phys., 13, 33793392, doi:10.5194/acp-13-3379-2013, 2013.

Hudman, R. C., Murray, L. T., Jacob, D. J., Millet, D. B., Turquety, S., Wu, S., Blake, D. R., Goldstein, A. H., Holloway, J., and Sachse, G. W.: Biogenic versus anthropogenic sources of CO in the United States, Geophys. Res. Lett., 35, L04801, doi:10.1029/2007GL032393, 2008.

Hurvich, C. M. and Tsai, C.-L.: Regression and time series model selection in small samples, Biometrika, 76, 297-307, doi:10.1093/biomet/76.2.297, 1989.

Jacob, D. J., Field, B. D., Jin, E. M., Bey, I., Li, Q., Logan, J. A., Yantosca, R. M., and Singh, H. B.: Atmospheric budget of acetone, J. Geophys. Res. Atmos., 107, 4100, doi:10.1029/2001JD000694, 2002.

Jaffe, D., Anderson, T., Covert, D., Kotchenruther, R., Trost, B., Danielson, J., Simpson, W., Berntsen, T., Karlsdottir, S., Blake, D., Harris, J., Carmichael, G., and Uno, I.: Transport of Asian air pollution to North America, Geophys. Res. Lett., 26, 711-714, doi:10.1029/1999GL900100, 1999.

Kaiser, J. W., Heil, A., Andreae, M. O., Benedetti, A., Chubarova, N., Jones, L., Morcrette, J.-J., Razinger, M., Schultz, M. G., Suttie, M., and van der Werf, G. R.: Biomass burning emissions estimated with a global fire assimilation system based on observed fire radiative power, Biogeosciences, 9, 527-554, doi:10.5194/bg-9-527-2012, 2012.

Karl, T., Potosnak, M., Guenther, A., Clark, D., Walker, J., Herrick, J. D., and Geron, C.: Exchange processes of volatile organic compounds above a tropical rain forest: Implications for modeling tropospheric chemistry above dense vegetation, J. Geophys. Res., 109, D18306, doi:10.1029/2004JD004738, 2004.

Khan, M. A. H., Cooke, M. C., Utembe, S. R., Archibald, A. T., Maxwell, P., Morris, W. C., Xiao, P., Derwent, R. G., Jenkin, M. E., Percival, C. J., Walsh, R. C., Young, T. D. S., Simmonds, P. G., Nickless, G., O'Doherty, S., and Shallcross, D. E.: A study of global atmospheric budget and distribution of acetone using global atmospheric model STOCHEM-CRI, Atmos. Environ., 112, 269-277, doi:10.1016/j.atmosenv.2015.04.056, 2015.

Kim, S., Karl, T., Guenther, A., Tyndall, G., Orlando, J., Harley, P., Rasmussen, R., and Apel, E.: Emissions and ambient distri- butions of Biogenic Volatile Organic Compounds (BVOC) in a ponderosa pine ecosystem: interpretation of PTR-MS mass spectra, Atmos. Chem. Phys., 10, 1759-1771, doi:10.5194/acp-101759-2010, 2010.

Kim, S. Y., Millet, D. B., Hu, L., Mohr, M. J., Griffis, T. J., Wen, D., Lin, J. C., Miller, S. M., and Longo, M.: Constraints on carbon monoxide emissions based on tall tower measurements in the US Upper Midwest., Environ. Sci. Technol., 47, 8316-8324, doi:10.1021/es4009486, 2013.

Lai, S. C., Baker, A. K., Schuck, T. J., Slemr, F., Brenninkmeijer, C. A. M., van Velthoven, P., Oram, D. E., Zahn, A., and Ziereis, H.: Characterization and source regions of 51 high-CO events observed during Civil Aircraft for the Regular Investigation of the Atmosphere Based on an Instrument Container (CARIBIC) flights between south China and the Philippines, 2005-2008, J. Geophys. Res., 116, D20308, doi:10.1029/2011JD016375, 2011.

Lamarque, J.-F., Bond, T. C., Eyring, V., Granier, C., Heil, A., Klimont, Z., Lee, D., Liousse, C., Mieville, A., Owen, B., Schultz, M. G., Shindell, D., Smith, S. J., Stehfest, E., Van Aardenne, J., Cooper, O. R., Kainuma, M., Mahowald, N., McConnell, J. R., Naik, V., Riahi, K., and van Vuuren, D. P.: Historical (1850-2000) gridded anthropogenic and biomass burning emissions of reactive gases and aerosols: methodology and application, Atmos. Chem. Phys., 10, 7017-7039, doi:10.5194/acp10-7017-2010, 2010.

Langford, B., Misztal, P. K., Nemitz, E., Davison, B., Helfter, C., Pugh, T. A. M., MacKenzie, A. R., Lim, S. F., and Hewitt, C. N.: Fluxes and concentrations of volatile organic compounds from a South-East Asian tropical rainforest, Atmos. Chem. Phys., 10, 8391-8412, doi:10.5194/acp-10-8391-2010, 2010.

Lee, M., Heikes, B. G., Jacob, D. J., Sachse, G., and Anderson, B.: Hydrogen peroxide, organic hydroperoxide, and formaldehyde as primary pollutants from biomass burning, J. Geophys. Res. Atmos., 102, 1301-1309, doi:10.1029/96JD01709, 1997.

Lefer, B. L., Talbot, R. W., Harriss, R. H., Bradshaw, J. D., Sandholm, S. T., Olson, J. O., Sachse, G. W., Collins, J., Shipham, M. A., Blake, D. R., Klemm, K. I., Klemm, O., Gorzelska, K., and Barrick, J.: Enhancement of acidic gases in biomass burning impacted air masses over Canada, J. Geophys. Res., 99, 1721-1737, doi:10.1029/93JD02091, 1994.

Lelieveld, J., Crutzen, P. J., Ramanathan, V., Andreae, M. O., Brenninkmeijer, C. A. M., Campos, T., Cass, G. R., Dickerson, R. R., Fischer, H., de Gouw, J. A., Hansel, A., Jefferson, A., Kley, D., de Laat, A. T. J., Lal, S., Lawrence, M. G., Lobert, J. M., Mayol-Bracero, O. L., Mitra, A. P., Novakov, T., Oltmans, S. J., Prather, K. A., Reiner, T., Rodhe, H., Scheeren, H. A., Sikka, D., and Williams, J.: The Indian Ocean Experiment: Widespread Air Pollution from South and Southeast Asia, Science, 291, 10311036, doi:10.1126/science.1057103, 2001.

Lelieveld, J., Evans, J. S., Fnais, M., Giannadaki, D., and Pozzer, A.: The contribution of outdoor air pollution sources to premature mortality on a global scale, Nature, 525, 367-371, 2015.

Lewis, A. C., Evans, M. J., Hopkins, J. R., Punjabi, S., Read, K. A., Purvis, R. M., Andrews, S. J., Moller, S. J., Carpenter, L. J., Lee, J. D., Rickard, A. R., Palmer, P. I., and Parrington, M.: The influence of biomass burning on the global distribution of selected non-methane organic compounds, Atmos. Chem. Phys., 13, 851-867, doi:10.5194/acp-13-851-2013, 2013. 
Li, J., Georgescu, M., Hyde, P., Mahalov, A., and Moustaoui, M.: Regional-scale transport of air pollutants: impacts of Southern California emissions on Phoenix ground-level ozone concentrations, Atmos. Chem. Phys., 15, 9345-9360, doi:10.5194/acp-159345-2015, 2015.

Li, M., Zhang, Q., Kurokawa, J., Woo, J.-H., He, K., Lu, Z., Ohara, T., Song, Y., Streets, D. G., Carmichael, G. R., Cheng, Y., Hong, C., Huo, H., Jiang, X., Kang, S., Liu, F., Su, H. and Zheng, B.: MIX: a mosaic Asian anthropogenic emission inventory under the international collaboration framework of the MICS-Asia and HTAP, Atmos. Chem. Phys., 17, 935-963, doi:10.5194/acp-17935-2017, 2017.

Lindinger, W., Hansel, A., and Jordan, A.: On-line monitoring of volatile organic compounds at pptv levels by means of proton-transfer-reaction mass spectrometry (PTR-MS) medical applications, food control and environmental research, Int. J. Mass Spectrom. Ion Process., 173, 191-241, doi:10.1016/S01681176(97)00281-4, 1998.

Madronich, S. and Flocke, S.: The Role of Solar Radiation in Atmospheric Chemistry, in Environmental Photochemistry, edited by: Boule, P., Springer Berlin Heidelberg, Berlin, Heidelberg, 1-26, 1999.

Madronich, S., Flocke, F., Zeng, J., Petropavlovskikh, I., and LeeTaylor, J.: Tropospheric Ultraviolet-Visible Model (TUV), version 5.0, NCAR/ACD, 2010.

Marandino, C. A., De Bruyn, W. J., Miller, S. D., Prather, M. J., and Saltzman, E. S.: Oceanic uptake and the global atmospheric acetone budget, Geophys. Res. Lett., 32, L15806, doi:10.1029/2005GL023285, 2005.

Mauzerall, D. L., Logan, J. A., Jacob, D. J., Anderson, B. E., Blake, D. R., Bradshaw, J. D., Heikes, B., Sachse, G. W., Singh, H., and Talbot, B.: Photochemistry in biomass burning plumes and implications for tropospheric ozone over the tropical South Atlantic, J. Geophys. Res. Atmos., 103, 8401-8423, doi:10.1029/97JD02612, 1998.

McKeen, S. A. and Liu, S. C.: Hydrocarbon ratios and photochemical history of air masses, Geophys. Res. Lett., 20, 2363-2366, doi:10.1029/93GL02527, 1993.

McKeen, S. A., Liu, S. C., Hsie, E.-Y., Lin, X., Bradshaw, J. D., Smyth, S., Gregory, G. L., and Blake, D. R.: Hydrocarbon ratios during PEM-WEST A: A model perspective, J. Geophys. Res. Atmos., 101, 2087-2109, doi:10.1029/95JD02733, 1996.

McKeen, S. A., Gierczak, T., Burkholder, J. B., Wennberg, P. O., Hanisco, T. F., Keim, E. R., Gao, R.-S., Liu, S. C., Ravishankara, A. R., and Fahey, D. W.: The photochemistry of acetone in the upper troposphere: A source of odd-hydrogen radicals, Geophys. Res. Lett., 24, 3177-3180, doi:10.1029/97GL03349, 1997.

McLachlan, G. and Peel, D.: Finite Mixture Models, John Wiley \& Sons, Inc., 1-39, 2000.

Miyoshi, A., Hatakeyama, S., and Washida, N.: OH radicalinitiated photooxidation of isoprene: An estimate of global CO production, J. Geophys. Res., 99, 18779-18787, doi:10.1029/94JD01334, 1994.

Moore, D. P., Remedios, J. J., and Waterfall, A. M.: Global distributions of acetone in the upper troposphere from MIPAS spectra, Atmos. Chem. Phys., 12, 757-768, doi:10.5194/acp-12-7572012, 2012.

Neumaier, M., Ruhnke, R., Kirner, O., Ziereis, H., Stratmann, G., Brenninkmeijer, C. A. M., and Zahn, A.: Im- pact of acetone (photo)oxidation on $\mathrm{HO}_{x}$ production in the UT/LMS based on CARIBIC passenger aircraft observations and EMAC simulations, Geophys. Res. Lett., 41, 3289-3297, doi:10.1002/2014GL059480, 2014.

Novelli, P. C., Masarie, K. A., Lang, P. M., Hall, B. D., Myers, R. C., and Elkins, J. W.: Reanalysis of tropospheric CO trends: Effects of the 1997-1998 wildfires, J. Geophys. Res., 108, 4464, doi:10.1029/2002JD003031, 2003.

Ohara, T., Akimoto, H., Kurokawa, J., Horii, N., Yamaji, K., Yan, X., and Hayasaka, T.: An Asian emission inventory of anthropogenic emission sources for the period 1980-2020, Atmos. Chem. Phys., 7, 4419-4444, doi:10.5194/acp-7-4419-2007, 2007.

Osman, M. K., Tarasick, D. W., Liu, J., Moeini, O., Thouret, V., Fioletov, V. E., Parrington, M., and Nédélec, P.: Carbon monoxide climatology derived from the trajectory mapping of global MOZAIC-IAGOS data, Atmos. Chem. Phys., 16, 10263-10282, doi:10.5194/acp-16-10263-2016, 2016.

Passant, N. R.: Speciation of UK emissions of non-methane volatile organic compounds, AEA Technology, report No. AEAT/ENV/R/0545, 2002.

Petetin, H., Thouret, V., Fontaine, A., Sauvage, B., Athier, G., Blot, R., Boulanger, D., Cousin, J.-M., and Nédélec, P.: Characterising tropospheric $\mathrm{O}_{3}$ and $\mathrm{CO}$ around Frankfurt over the period 1994-2012 based on MOZAIC-IAGOS aircraft measurements, Atmos. Chem. Phys., 16, 15147-15163, doi:10.5194/acp16-15147-2016, 2016.

Petzold, A., Thouret, V., Gerbig, C., Zahn, A., Brenninkmeijer, C. A. M., Gallagher, M., Hermann, M., Pontaud, M., Ziereis, H., Boulanger, D., Marshall, J., Nédélec, P., Smit, H. G. J., Friess, U., Flaud, J.-M., Wahner, A., Cammas, J.-P., Volz-Thomas, A. and IAGOS TEAM: Global-scale atmosphere monitoring by inservice aircraft - current achievements and future prospects of the European Research Infrastructure IAGOS, Tellus B, 67, 124, doi:10.3402/tellusb.v67.28452, 2015.

Pöschl, U., Williams, J., Hoor, P., Fischer, H., Crutzen, P. J., Warneke, C., Holzinger, R., Hansel, A., Jordan, A., Lindinger, W., Scheeren, H. A., Peters, W., and Lelieveld, J.: High Acetone Concentrations throughout the $0-12 \mathrm{~km}$ Altitude Range over the Tropical Rainforest in Surinam, J. Atmos. Chem., 38, 115-132, doi:10.1023/A:1006370600615, 2001.

Pozzer, A., Pollmann, J., Taraborrelli, D., Jöckel, P., Helmig, D., Tans, P., Hueber, J., and Lelieveld, J.: Observed and simulated global distribution and budget of atmospheric $\mathrm{C}_{2}-\mathrm{C}_{5}$ alkanes, Atmos. Chem. Phys., 10, 4403-4422, doi:10.5194/acp-10-44032010, 2010.

Reiner, T., Sprung, D., Jost, C., Gabriel, R., Mayol-Bracero, O. L., Andreae, M. O., Campos, T. L., and Shelter, R. E.: Chemical characterization of pollution layers over the tropical Indian Ocean: Signatures of emissions from biomass and fossil fuel burning, J. Geophys. Res. Atmos., 106, 28497-28510, doi:10.1029/2000JD900695, 2001.

Sakamoto, K. M., Allan, J. D., Coe, H., Taylor, J. W., Duck, T. J., and Pierce, J. R.: Aged boreal biomass-burning aerosol size distributions from BORTAS 2011, Atmos. Chem. Phys., 15, 16331646, doi:10.5194/acp-15-1633-2015, 2015.

Schade, G. W. and Goldstein, A. H.: Seasonal measurements of acetone and methanol: Abundances and implications for 
atmospheric budgets, Global Biogeochem. Cy., 20, GB1011, doi:10.1029/2005GB002566, 2006.

Scharffe, D., Slemr, F., Brenninkmeijer, C. A. M., and Zahn, A.: Carbon monoxide measurements onboard the CARIBIC passenger aircraft using UV resonance fluorescence, Atmos. Meas. Tech., 5, 1753-1760, doi:10.5194/amt-5-1753-2012, 2012.

Simpson, I. J., Akagi, S. K., Barletta, B., Blake, N. J., Choi, Y., Diskin, G. S., Fried, A., Fuelberg, H. E., Meinardi, S., Rowland, F. S., Vay, S. A., Weinheimer, A. J., Wennberg, P. O., Wiebring, P., Wisthaler, A., Yang, M., Yokelson, R. J., and Blake, D. R.: Boreal forest fire emissions in fresh Canadian smoke plumes: $\mathrm{C}_{1}-\mathrm{C}_{10}$ volatile organic compounds (VOCs), $\mathrm{CO}_{2}, \mathrm{CO}, \mathrm{NO}_{2}$, $\mathrm{NO}, \mathrm{HCN}$ and $\mathrm{CH}_{3} \mathrm{CN}$, Atmos. Chem. Phys., 11, 6445-6463, doi:10.5194/acp-11-6445-2011, 2011.

Sindelarova, K., Granier, C., Bouarar, I., Guenther, A., Tilmes, S., Stavrakou, T., Müller, J.-F., Kuhn, U., Stefani, P., and Knorr, W.: Global data set of biogenic VOC emissions calculated by the MEGAN model over the last 30 years, Atmos. Chem. Phys., 14, 9317-9341, doi:10.5194/acp-14-9317-2014, 2014.

Singh, H. B., Salas, L. J., and Viezee, W.: Global distribution of peroxyacetyl nitrate, Nature, 321, 588-591, doi:10.1038/321588a0, 1986.

Singh, H. B., Herlth, D., O'Hara, D., Zahnle, K., Bradshaw, J. D., Sandholm, S. T., Talbot, R., Crutzen, P. J., and Kanakidou, M.: Relationship of peroxyacetyl nitrate to active and total odd nitrogen at northern high latitudes: Influence of reservoir species on $\mathrm{NO}_{x}$ and $\mathrm{O}_{3}$, J. Geophys. Res., 97, 16523-16530, doi:10.1029/91JD00890, 1992.

Singh, H. B., O’Hara, D., Herlth, D., Sachse, W., Blake, D. R., Bradshaw, J. D., Kanakidou, M., and Crutzen, P. J.: Acetone in the atmosphere: Distribution, sources, and sinks, J. Geophys. Res., 99, 1805-1819, doi:10.1029/93JD00764, 1994.

Singh, H. B., Kanakidou, M., Crutzen, P. J., and Jacob, D. J.: High concentrations and photochemical fate of oxygenated hydrocarbons in the global troposphere, Nature, 378, 50-54, 1995.

Singh, H. B., Salas, Chatfield, Czech, Fried, Walega, Evans, Field, Jacob, Blake, Heikes, Talbot, Sachse, Crawford, Avery, Sandholm and Fuelberg: Analysis of the atmospheric distribution, sources, and sinks of oxygenated volatile organic chemicals based on measurements over the Pacific during TRACE-P, J. Geophys. Res., 109, D15S07, doi:10.1029/2003JD003883, 2004.

Singh, H. B., Anderson, B. E., Brune, W. H., Cai, C., Cohen, R. C., Crawford, J. H., Cubison, M. J., Czech, E. P., Emmons, L., and Fuelberg, H. E.: Pollution influences on atmospheric composition and chemistry at high northern latitudes: Boreal and California forest fire emissions, Atmos. Environ., 44, 4553-4564, doi:10.1016/j.atmosenv.2010.08.026, 2010.

Spivakovsky, C. M., Logan, J. A., Montzka, S. A., Balkanski, Y. J., Foreman-Fowler, M., Jones, D. B. A., Horowitz, L. W., Fusco, A. C., Brenninkmeijer, C. A. M., Prather, M. J., Wofsy, S. C., and McElroy, M. B.: Three-dimensional climatological distribution of tropospheric $\mathrm{OH}$ : Update and evaluation, J. Geophys. Res. Atmos., 105, 8931-8980, doi:10.1029/1999JD901006, 2000.

Sprung, D. and Zahn, A.: Acetone in the upper troposphere/lowermost stratosphere measured by the CARIBIC passenger aircraft: Distribution, seasonal cycle, and variability, J. Geophys. Res., 115, D16301, doi:10.1029/2009JD012099, 2010.

Stein, O., Schultz, M. G., Bouarar, I., Clark, H., Huijnen, V., Gaudel, A., George, M., and Clerbaux, C.: On the wintertime low bias of Northern Hemisphere carbon monoxide found in global model simulations, Atmos. Chem. Phys., 14, 9295-9316, doi:10.5194/acp-14-9295-2014, 2014.

Stiller, G. P., von Clarmann, T., Glatthor, N., Höpfner, M., Kellmann, S., Kimmich, E., Linden, A., Milz, M., Steck, T., and Fischer, H.: Retrievability of Upper Tropospheric Species and Parameters from MIPAS/ENVISAT Data, edited by: Borrell, P., Borrell, P. M., Burrows, J. P., and Platt, U., Springer Berlin Heidelberg, Berlin, Heidelberg, 167-180, 2004.

Stohl, A., James, P., Forster, C., Spichtinger, N., Marenco, A., Thouret, V., and Smit, H. G. J.: An extension of Measurement of Ozone and Water Vapour by Airbus Inservice Aircraft (MOZAIC) ozone climatologies using trajectory statistics, J. Geophys. Res. Atmos., 106, 27757-27768, doi:10.1029/2001JD000749, 2001.

Stohl, A., Eckhardt, S., Forster, C., James, P., Spichtinger, N., and Seibert, P.: A replacement for simple back trajectory calculations in the interpretation of atmospheric trace substance measurements, Atmos. Environ., 36, 4635-4648, doi:10.1016/S13522310(02)00416-8, 2002.

Sugiura, N.: Further analysts of the data by akaike' s information criterion and the finite corrections, Commun. Stat.-Theor. M., 7, 13-26, doi:10.1080/03610927808827599, 1978.

Tereszchuk, K. A., González Abad, G., Clerbaux, C., Hadji-Lazaro, J., Hurtmans, D., Coheur, P.-F., and Bernath, P. F.: ACE-FTS observations of pyrogenic trace species in boreal biomass burning plumes during BORTAS, Atmos. Chem. Phys., 13, 4529-4541, doi:10.5194/acp-13-4529-2013, 2013.

Thouret, V., Cammas, J.-P., Sauvage, B., Athier, G., Zbinden, R., Nédélec, P., Simon, P., and Karcher, F.: Tropopause referenced ozone climatology and inter-annual variability (1994-2003) from the MOZAIC programme, Atmos. Chem. Phys., 6, 1033-1051, doi:10.5194/acp-6-1033-2006, 2006.

Turquety, S., Logan, J. A., Jacob, D. J., Hudman, R. C., Leung, F. Y., Heald, C. L., Yantosca, R. M., Wu, S., Emmons, L. K., Edwards, D. P., and Sachse, G. W.: Inventory of boreal fire emissions for North America in 2004: Importance of peat burning and pyroconvective injection, J. Geophys. Res., 112, D12S03, doi:10.1029/2006JD007281, 2007.

van der Werf, G. R., Randerson, J. T., Giglio, L., Collatz, G. J., Kasibhatla, P. S., and Arellano, A. F.: Interannual variability in global biomass burning emissions from 1997 to 2004, Atmos. Chem. Phys., 6, 3423-3441, doi:10.5194/acp-6-3423-2006, 2006.

van der Werf, G. R., Randerson, J. T., Giglio, L., Collatz, G. J., Mu, M., Kasibhatla, P. S., Morton, D. C., DeFries, R. S., Jin, Y., and van Leeuwen, T. T.: Global fire emissions and the contribution of deforestation, savanna, forest, agricultural, and peat fires (19972009), Atmos. Chem. Phys., 10, 11707-11735, doi:10.5194/acp10-11707-2010, 2010.

van Velthoven, P. F. J.: Meteorological analysis of CARIBIC by KNMI, http://projects.knmi.nl/campaign_support/CARIBIC/, last access: 1 September 2016.

Warneke, C., de Gouw, J. A., Kuster, W. C., Goldan, P. D., and Fall, R.: Validation of Atmospheric VOC Measurements by Proton-Transfer- Reaction Mass Spectrometry Using a GasChromatographic Preseparation Method, Environ. Sci. Technol., 37, 2494-2501, doi:10.1021/es026266i, 2003. 
Warneke, C., de Gouw, J. A., Stohl, A., Cooper, O. R., Goldan, P. D., Kuster, W. C., Holloway, J. S., Williams, E. J., Lerner, B. M., McKeen, S. A., Trainer, M., Fehsenfeld, F. C., Atlas, E. L., Donnelly, S. G., Stroud, V., Lueb, A., and Kato, S.: Biomass burning and anthropogenic sources of $\mathrm{CO}$ over New England in the summer 2004, J. Geophys. Res. Atmos., 111, D23S15, doi:10.1029/2005JD006878, 2006.

Warneke, C., Roberts, J. M., Veres, P., Gilman, J., Kuster, W. C., Burling, I., Yokelson, R., and de Gouw, J. A.: VOC identification and inter-comparison from laboratory biomass burning using PTR-MS and PIT-MS, Int. J. Mass Spectrom., 303, 6-14, doi:10.1016/j.ijms.2010.12.002, 2011.

Waterfall, A. M., Remedios, J. J., Allen, G., and Sembhi, H.: Infrared remote sensing of organic compounds in the upper troposphere, Proceedings of the ENVISAT Symposium, Salzburg, September, 2004.

Williamson, J. H.: Least-squares fitting of a straight line, Can. J. Phys., 46, 1845-1847, doi:10.1139/p68-523, 1968.

Wisthaler, A., Hansel, A. Dickerson, R. R., and Crutzen, P.: Organic trace gas measurements by PTR-MS during INDOEX 1999, J. Geophys. Res., 107, 8024, doi:10.1029/2001JD000576, 2002.

Yokelson, R. J., Andreae, M. O., and Akagi, S. K.: Pitfalls with the use of enhancement ratios or normalized excess mixing ratios measured in plumes to characterize pollution sources and aging, Atmos. Meas. Tech., 6, 2155-2158, doi:10.5194/amt-62155-2013, 2013.

York, D.: Least-Squares fitting of a straight line, Can. J. Phys., 44, 1079-1086, doi:10.1139/p66-090, 1966.
York, D., Evensen, N. M., Martínez, M. L., and De Basabe Delgado, J.: Unified equations for the slope, intercept, and standard errors of the best straight line, Am. J. Phys., 72, 367, doi:10.1119/1.1632486, 2004.

Zahn, A. and Brenninkmeijer, C. A. M.: New Directions: A Chemical Tropopause Defined, Atmos. Environ., 37, 439-440, doi:10.1016/S1352-2310(02)00901-9, 2003.

Zahn, A., Brenninkmeijer, C. A. M., Asman, W. A. H., Crutzen, P. J., Heinrich, G., Fischer, H., Cuijpers, J. W. M., and van Velthoven, P. F. J.: Budgets of $\mathrm{O}_{3}$ and $\mathrm{CO}$ in the upper troposphere: CARIBIC passenger aircraft results 1997-2001, J. Geophys. Res. Atmos., 107, 4337, doi:10.1029/2001JD001529, 2002.

Zahn, A., Brenninkmeijer, C. A. M., and van Velthoven, P. F. J.: Passenger aircraft project CARIBIC 1997-2002, Part I: the extratropical chemical tropopause, Atmos. Chem. Phys. Discuss., 4, 1091-1117, doi:10.5194/acpd-4-1091-2004, 2004.

Zahn, A., Weppner, J., Widmann, H., Schlote-Holubek, K., Burger, B., Kühner, T., and Franke, H.: A fast and precise chemiluminescence ozone detector for eddy flux and airborne application, Atmos. Meas. Tech., 5, 363-375, doi:10.5194/amt-5-363-2012, 2012.

Zbinden, R. M., Thouret, V., Ricaud, P., Carminati, F., Cammas, J.P., and Nédélec, P.: Climatology of pure tropospheric profiles and column contents of ozone and carbon monoxide using MOZAIC in the mid-northern latitudes $\left(24^{\circ} \mathrm{N}\right.$ to $\left.50^{\circ} \mathrm{N}\right)$ from 1994 to 2009, Atmos. Chem. Phys., 13, 12363-12388, doi:10.5194/acp13-12363-2013, 2013. 